\title{
Human cytomegalovirus infection: A considerable issue following allogeneic hematopoietic stem cell transplantation (Review)
}

\author{
XINYI ZHOU, NAN JIN and BAOAN CHEN \\ Department of Hematology and Oncology, Zhongda Hospital, Medical School, \\ Southeast University, Nanjing, Jiangsu 210009, P.R. China
}

Received July 23, 2020; Accepted December 23, 2020

DOI: $10.3892 / \mathrm{ol} .2021 .12579$

\begin{abstract}
Cytomegalovirus (CMV) is an opportunistic virus, whereby recipients are most susceptible following allogeneic hematopoietic stem cell transplantation (allo-HSCT). With the development of novel immunosuppressive agents and antiviral drugs, accompanied with the widespread application of prophylaxis and preemptive treatment, significant developments have been made in transplant recipients with human (H)CMV infection. However, HCMV remains an important cause of short- and long-term morbidity and mortality in transplant recipients. The present review summarizes the molecular mechanism and risk factors of HCMV reactivation following allo-HSCT, the diagnosis of CMV infection following allo-HSCT, prophylaxis and treatment of HCMV infection, and future perspectives. All relevant literature were retrieved from PubMed and have been reviewed.
\end{abstract}

\section{Contents}

1. Introduction

2. Mechanism of HCMV reactivation following allo-HSCT

3. Risk factors of HCMV reactivation following allo-HSCT

4. Prediction of CMV infection following allo-HSCT

5. Diagnosis of CMV infection following allo-HSCT

6. HCMV infection prophylaxis

Correspondence to: Professor Baoan Chen, Department of Hematology and Oncology, Zhongda Hospital, Medical School, Southeast University, 87 Dingjiaqiao Street, Nanjing, Jiangsu 210009, P.R. China

E-mail: cba8888@hotmail.com

Abbreviations: allo-HSCT, allogeneic hematopoietic stem cell transplantation; HCMV, human-cytomegalovirus; GVHD, graft vs. host disease; IL, interleukin; TCM, central memory T cells; NPS, non-protective signature; PS, protective signature; SOCS, cytokine signaling genes; LET, letermovir; AML, acute myeloid leukemia

Key words: CMV, allo-HSCT, prophylaxis, preemptive treatment, cellular immunotherapy, hematological malignancy
7. Treatment of HCMV infection

8. Leukemia relapse following allo-HSCT

9. Conclusions

\section{Introduction}

Allogeneic hematopoietic stem cell transplantation (allo-HSCT) is an effective treatment for hematological tumors (1), which has recently been demonstrated to improve therapeutic effects in patients with autoimmune diseases (2). Due to the lengthy procedure of immune reconstruction, particularly after the use of high-intensity chemotherapy to suppress hematopoiesis and the application of T-cell depletion, the occurrence of post-transplant infection has become a prominent complication following allo-HSCT (3). Viral infection is the leading cause of infectious mortality in $30 \%$ of patients following transplantation (4). For decades, opportunistic cytomegalovirus (CMV) infection has been the most common complication following allo-HSCT, resulting in mortality (5). Recipients may experience primary human (H)CMV infection, re-infection, re-ignition and co-infection following transplantation (6). CMV immunoglobulin G (IgG) is a marker of HCMV infection, the positive rate of which reaches $50.0-92.2 \%$ in healthy adults worldwide, with rates increasing with age (7-10). Following initial HCMV infection, healthy individuals may exhibit no obvious symptoms in their lifetime, and HCMV can also exist in a latent state $(11,12)$. However, infection in immunosuppressed individuals may be more likely to occur due to lack of CMV-specific cytotoxic and helper T cells (13). Active HCMV infection is one of the most common complications following allo-HSCT, which may be fatal for patients receiving transplantation (13). In addition to HCMV-associated diseases that exhibit a high mortality, such as asymptomatic viremia, DNAemia, antigenemia, esophagitis, gastroenteritis, hepatitis, retinitis, pneumonia and encephalitis, HCMV infection is also associated with graft vs. host disease (GVHD), and the increased incidence of other pathogenic infections such as Epstein-Barr virus, varicella-zoster virus and child adenovirus (13).

HCMV is a double-stranded DNA $\beta$-herpes virus (235,000 base pairs), also known as herpes virus 5 , that contains $>200$ potential open reading frames $(14,15)$. HCMV synthesizes a series of proteins after entering the host cell, 
which are divided into immediate early protein (IE), delayed early protein and late protein, according to the time at which they are produced (16). These proteins are synthesized within 2, 24 and after $24 \mathrm{~h}$, respectively (17).

\section{Mechanism of HCMV reactivation following allo-HSCT}

HCMV is latent in the peripheral monocytes and endothelial cells of several organs. Distinct organs, tissues and cell transplants can transmit HCMV. The latency of primary HCMV infection relies on its multiple and complex immune evasion mechanisms to evade the host immune response $(18,19)$. Interferon (IFN)-mediated innate immunity is one of the first lines of the host defense mechanism $(12,20)$. Specific genes encoded by HCMV are associated with the downregulation of IFN-mediated innate immunity (11). In addition, HCMV infection upregulates the function of ligands targeting the natural killer cell activating receptor, natural killer group 2 , member D (21). However, the presentation of these ligands on the surface of cells is suppressed by certain HCMV-induced genes, including UL16 and UL142, which encode proteins, and microRNA (miRNA/miR)-UL112, which encodes a miRNA $(12,22)$. Furthermore, HCMV influences the expression of CD155 by upregulating UL141, exposing the receptor on the cell surface to avoid recognition (23). Interleukin (IL)-10 serves as an inhibitor, suppressing the secretion of several cytokines from helper $\mathrm{T}$ cells, including IFN- $\gamma$ and IL-2 $(24,25)$. This in turn attenuates the production of inflammatory cytokines from monocytes and macrophages, decreasing the expression of major histocompatibility complex (MHC)-II molecules and subsequent antigen presentation (26). IL-10 also encodes proteins that act as host inflammatory cytokines, resulting in a decrease of local cytokine effectiveness (27). Cheung et al (20) suggested that HCMV is associated with the production of IL-10 homologs, which serves an immunosuppressive role during the incubation period of infection. In addition, US2 and US11 have been demonstrated to inhibit the degradation of target MHC-I molecules within the cytoplasm, resulting in destruction by proteasomes. US3 interferes with molecular chaperone related antigen peptide loading by containing MHC-I within the endoplasmic reticulum. Furthermore, US6 suppresses the transporter associated with MHC-I antigen processing. The expression of these genes allow infected cells to escape immune clearance (Fig. 1) (28,29). However, latent infection is established when the virus spreads to and is persistently present in various cells, including myeloid cells (such as monocytes and CD34 cells), endothelial cells, epithelial cells (including retinal cells), smooth muscle cells, fibroblasts, leukocytes and dendritic cells $(30,31)$. Endothelial and hematopoietic cell infection may lead to the spread of the virus within various systems of the host (32). In addition, the infection of ubiquitous cell types, such as fibroblasts and smooth muscle cells, provides a platform for effective virus proliferation (33). CMV-specific CD4 and CD8 T cells appear successively in the peripheral blood. CD4 T cells secrete helper T cell-type cy tokines, such as IFN- $\gamma$ and tumor necrosis factor (TNF)- $\alpha$. CD8 T cells can lyse CMV-peptides to present target cells $(34,35)$. However, during latent infection, these specific T cells fail to eliminate HCMV (12).
Following myeloablative conditioning, recipient immune cells and malignant or defective cells are eliminated, meaning that allo-HSCT recipients must go through a period of pancytopenia for days to weeks depending on the source of stem cells (5). The adaptive immune system is subsequently restored slowly over a period of several months to $1-2$ years (36). In the early stages following allo-HSCT, transferred immunity is only maintained for a limited period, after which a gradual decrease is observed (37). In addition to hematological disease itself and the drugs administered during myeloablative conditioning, immunosuppressive agents are used to prevent GVHD, which can further delay immune reconstruction, increasing patient susceptibility to several opportunistic infections $(12,38)$. After allo-HSCT, the immune system is gradually restored following neutrophil engraftment; however, the recovery of lymphocyte function takes an extended period (39). At this point, CMV ends its latent period (3). It has been demonstrated that the activation of multiple pathways can reactivate latent HCMV (40). However, whether a cross-over mechanism exists between each pathway is yet to be elucidated. Anti-lymphocyte antibodies used for induction therapy can induce TNF- $\alpha$ secretion and activate the $\mathrm{NK}-\kappa \mathrm{B} 1$ pathway, stimulating the transcription of the HCMV IE gene, leading to the resurgence of latent HCMV (41). Simultaneously, antibody treatment can clear T cells, resulting in the lack of T-cell immunity against CMV and decreased immunological surveillance for HCMV (42). In the event of rejection, latent HCMV can be activated through the NK- $\kappa \mathrm{B} 1$ pathway (38). Inflammation andstresscan activate the expression of IE through the cAMP pathway (43). Ischemia-reperfusion injury activates activator protein-1 (AP-1) through the AP-1 pathway (38). Rejection following transplantation typically occurs prior to HCMV activation (44). Activation of the NK- $\mathrm{B} 1$ pathway results in the transcription of HCMV genes that induce viral infection (45). Subsequent anti-rejection therapy, such as hormonal shock therapy or the application of antithymocyte globulin (ATG) drugs, inhibit or destroy immune function against HCMV (Fig. 2) (44).

T cell-driven cellular immunity is known to control CMV replication, and the lack or delay of CMV-specific CD4- and CD8-T lymphocyte recovery can lead to CMV recurrence and CMV-associated diseases (46-48). CMV reactivation is usually associated with a high frequency of GVHD, which may partially lead to enhanced T-cell reconstitution in patients with HCMV infection (12). A previous study demonstrated that the presence of CMV-specific cytotoxic T lymphocytes (CTL) in CMV seropositive recipients is associated with faster T-cell reconstitution, which may induce donor allogeneic reactivity (49). The successful elimination of residual host hematopoietic function is therefore reflected by the complete donor chimerism (50). In addition, suppression of cytokine signaling genes (SOCS) can also explain the close association between CMV reactivation, GVHD and donor chimerism (51). SOCS is associated with the regulation of T-cell homeostasis and the negative feedback mechanism induced by cytokine signaling, involving IFN- $\gamma$ or interleukins (51). Previous studies on SOCS gene expression have demonstrated that SOCS1 expression is significantly lower in patients with GVHD compared with post-transplant patients without GVHD $(37,51,52)$. Furthermore, SOCS1 expression is 


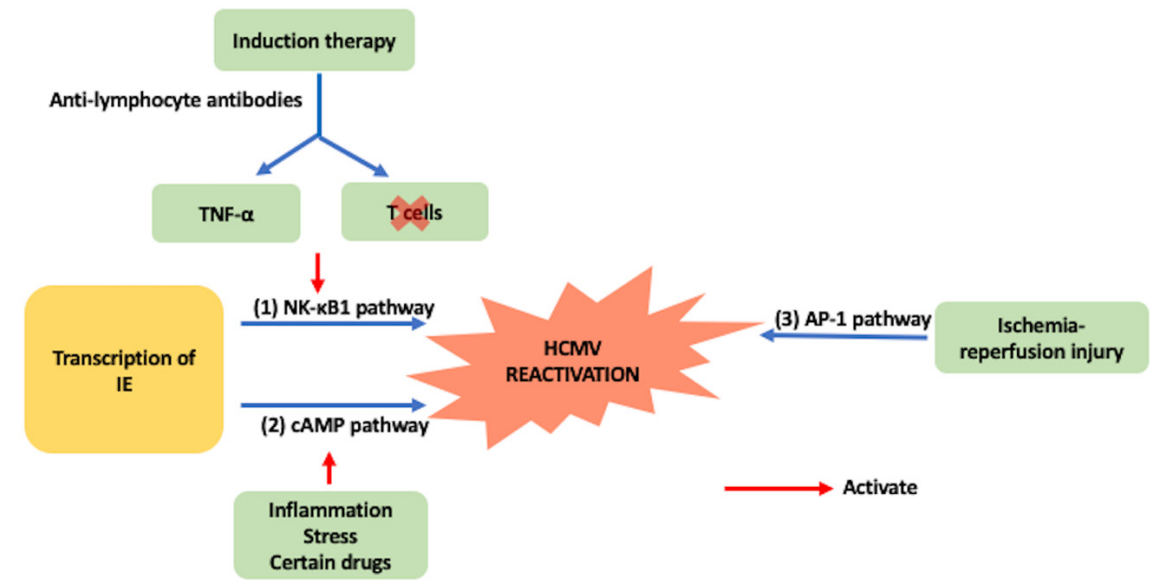

Figure 1. Mechanism of HCMV reactivation. There are three main pathways associated with the reactivation of HCMV. (1) The NK-кB1 pathway: Anti-lymphocyte antibodies used in induction therapy can induce TNF- $\alpha$ secretion and clear T cells, which subsequently activates the NK-kB1 pathway, stimulating the transcription of the HCMV IE gene, leading to the resurgence of latent HCMV. (2) The cAMP pathway: Inflammation, stress activate the expression of IE through this pathway. (3) The AP-1 pathway: Ischemia-reperfusion injury activates AP-1 through this pathway. HCMV, human cytomegalovirus; TNF, tumor necrosis factor; IE, immediate early protein; AP-1, activator protein-1.

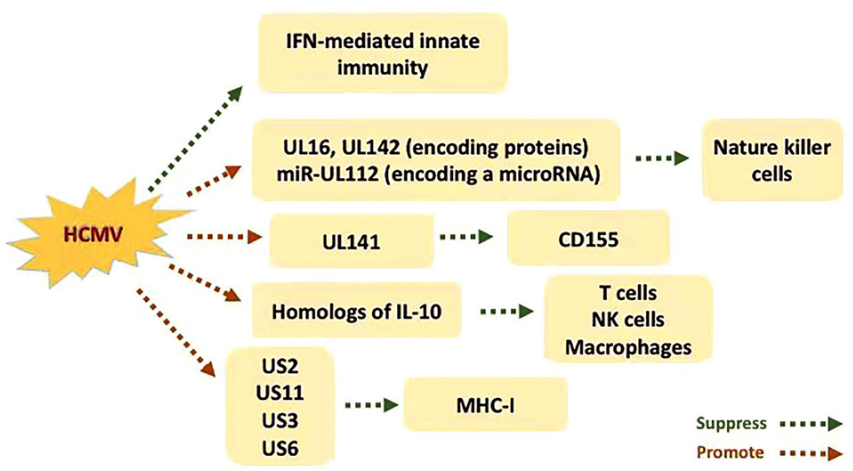

Figure 2. Immune evasion mechanism of HCMV. Due to the gene encoded by HCMV, effects of IFN-mediated innate immunity are downregulated, and HCMV infection suppresses the function of ligands for nature killer cells via UL16, UL142 (encoding proteins) and miR-UL112 (encoding a miRNA). HCMV also influences CD155 expression, which is exposed on the cell surface following infection, by encoding UL141 to avoid recognition. In addition, HCMV is associated with the production of homologs of IL-10, which play an immunosuppressive role during the period of incubation. US2, US11, US3 and US6 expression allow infected cells to escape immune clearance. HCMV, human cytomegalovirus; IFN, interferon; miRNA/miR, microRNA IL, interleukin; IE, immediate early protein; AP-1, activator protein-1; MHC, major histocompatibility complex.

significantly lower in patients with chronic GVHD than those with acute GVHD (53). In addition, our previous study revealed that SOCS1 expression is significantly higher in patients with CMV reactivation than those with non-CMV reactivation (53). Conversely, SOCS3 expression is decreased in all HSCT recipients $(53,54)$. These data explain the molecular association between HCMV reactivation and allo-HSCT.

\section{Risk factors of HCMV reactivation following allo-HSCT}

$C M V$ donor $(D) /$ recipient $(R)$ serostatus. CMV serological status, that is, CMV-IgG (+) and (-), is one of the main risk factors associated with the incidence and mortality of patients with CMV disease following stem cell transplantation (55).
According to previous studies, recipients with a negative CMV serostatus receiving CMV seropositive donor grafts (D+/R-) have the highest risk of mortality following transplantation $(56,57)$. However, other studies have demonstrated that although the risk of infection in patients that are $D+/ R+$ is lower, the survival time of grafts and recipients is shorter than that of D+/R-individuals (58-60). However, the association between CMV serostatus and CMV-positive recipients $(\mathrm{R}+)$ remains controversial.

Graft source. Currently, the main sources of graft stem cells for transplantation are bone marrow, peripheral blood stem cells and umbilical cord blood (61). Trenschel et al (62) demonstrated that the incidence of persistent CMV antigenemia and CMV-related interstitial pneumonia following peripheral blood stem cell transplantation significantly decreases compared with bone marrow transplantation, which may be due to the varying immune reconstitution times following different graft transplantations. In addition, Uppuluri et al (63) reported that the incidence rate of $\mathrm{HCMV}$ reactivation in pediatric patients receiving allo-HSCT from matched-related donors, unrelated peripheral blood stem cells, unrelated umbilical cords and mismatched or haploidentical grafts were 3.0, 33.3, 17.4 and 36.5\%, respectively. Furthermore, Boeckh et al (64) suggested that patients receiving autologous stem cell transplantation have a lower CMV disease morbidity than patients receiving allogeneic stem cell transplantation.

Population of CMV-specific T cells. In healthy individuals, both $\mathrm{CD}^{+}$and $\mathrm{CD}^{+}{ }^{+} \mathrm{T}$ cells, which target certain $\mathrm{CMV}$ peptides (65), are significant for the prevention of CMV infection (66). The proportion of the immune response devoted to CMV increases with age in seropositive individuals. The T-cell repertoire and subdominant responses also incorporate other CMV proteins, including glycoprotein- $\mathrm{H}$ and pp28 (67). CD8 ${ }^{+}$cells recognize the epitopes of CMV proteins in a manner that is determined by human leukocyte antigen (HLA) (67). The major tegument protein, phosphoprotein 65 (pp65), and IE-1 are the most extensively studied 
immune targets in HSCT recipients $(68,69)$. According to previous studies, $\mathrm{CMV}$-specific $\mathrm{CD} 8^{+}$central memory T-cell (TCM) levels in patients before HSCT serves a significant role in long term clinical response (70,71). Liu et al (72) revealed that patients with higher populations of $\mathrm{CMV}$-specific $\mathrm{CD} 8^{+}$ TCM exhibit an improved therapeutic response than those with low populations of $\mathrm{CMV}$-specific $\mathrm{CD} 8^{+} \mathrm{TCM}$. In addition, the morbidity of CMV-related diseases is lower in the same patients. LaMattina et al (73) demonstrated that CMV-specific $\mathrm{T}$ cells are associated with the proliferation of the other T-cell subsets and clonogenesis.

Immunosuppressive regimen. Patients are routinely administered thymoglobulin, cyclosporine, alemtuzumab and glucocorticoid shock therapy as treatment following allo-HSCT (74). However, these drugs have been reported to increase the risk of HCMV reactivation $(73,75)$. In addition, the increased use of immunosuppressive agents is an important factor that affects HCMV reactivation (76). Kobashigawa et al (77) revealed that the combination of tacrolimus and mycophenolate mofetil achieve a more effective response with less side effects. Furthermore, previous studies have suggested that the application of everolimus and calcineurin inhibitors without steroid treatment can markedly improve the incidence rate of CMV antigenemia (78-80). Collectively, it has been demonstrated that immunosuppression regimens are closely associated with CMV infection.

GVHD. GVHD is caused by a series of 'cytokine storms' stimulated by $\mathrm{T}$ cells in allogeneic donor grafts following transplantation, which greatly enhances its immune response to recipient antigens (81). Target cells are subsequently used to initiate cytotoxic attacks, of which the skin, liver and intestine are the primary targets (82). Miller et al (83) demonstrated that CMV-specific cytotoxic T cells may serve an important role in CMV infection control. The incidence of GVHD and the treatment of immunosuppression limits the proliferation of CMV-specific cytotoxic T cells, thus increasing the chance of CMV infection (84). Nutrient absorption and the physical fitness of patients is weakened, which further increases the risk of CMV infection $(85,86)$. Univariate analysis has revealed that the rate of CMV infection in patients with acute grade 0-I GVHD following transplantation is $51.9 \%$, and the rate of patients with acute grade II-IV GVHD is $92.3 \%$ (87). In addition, multivariate analysis has demonstrated that patients with acute grade II-IV GVHD exhibit a higher CMV infection rate following transplantation (87).

Other risk factors. Other risk factors for reactivation in allo-HSCT recipients include advanced age, co-infection with human herpes virus 6 or human herpes virus and HLA incompatibility (88).

\section{Prediction of CMV infection following allo-HSCT}

The prediction of CMV-related diseases is important. Due to primary hematological diseases, certain drugs (such as ATG) and immunosuppressive therapies applied after allo-HSCT or GVHD compromise the immune system of patients (89). In addition, the speed of immune system recovery in different recipients is another contributing factor (90). Given that the resistance of patients to CMV following allo-HSCT mainly depends on CMV-specific cytotoxic T-cells, CMV-specific cell-mediated immunity serves an important role in reducing the risk of CMV-related diseases (90). Yong et al (91) revealed that the quantification of $\mathrm{CMV}$-specific $\mathrm{T}$ cells may predict the risk of CMV-related disease. Furthermore, as CMV-specific $T$ cells can be measured by the production of IFN $-\gamma$, IFN $-\gamma$ ELISpot assays serve an important role in predicting the immunity of CMV-specific T cells (92-94). In addition, Camargo et al (41) suggested that determining the phenotype of CMV-specific T cells, the non-protective signature [NPS; IL-2 IFN- $\gamma^{+}$TNF- $\alpha$ and macrophage inflammatory protein $\left.\left(\mathrm{MIP}-1 \beta^{+}\right)\right]$and the protective signature (PS; IL-2 $2^{+} \mathrm{IFN}-\gamma^{+}$ TNF- $\alpha^{+}$and MIP- $1 \beta^{+}$), alone or in combination may be used to determine the risk of CMV infection more efficiently. In addition, patients with high NPS and low PS exhibit an increased risk of CMV infection (41). Low levels of NKG2C copies within the donor and the DNA load of torque teno virus may also be a predictor of CMV infection $(95,96)$. Previous studies have demonstrated that suppression of SOCS, which is associated with IFN- $\gamma$ or interleukin negative feedback, and with measuring the function of T cells (97), can explain the association between CMV reactivation, GVHD and donor chimerism (52-54). SOCS1 is expressed at low levels in patients with GVHD than those without GVHD, and in patients with chronic GVHD than those with acute GVHD (54). SOCS1 expression is also higher in patients with reactivated CMV (53). In a previous study where patients simultaneously exhibited CMV reactivation and GVHD, SOCS1 expression decreased compared with patients only exhibiting CMV reactivation (54). However, SOCS3 expression was downregulated in all patients following transplantation (51).

For patients with a high risk of CMV-related disease, several techniques used for immune monitoring, such as measuring CMV-specific T-cell function, are effective for the improvement of transplantation outcome. However, further studies are required to confirm these results.

\section{Diagnosis of CMV infection following allo-HSCT}

CMV-mediated disease is diagnosed when patients test positive for CMV serum antigens or produce a positive viral culture following infected tissue analysis, whilst demonstrating corresponding clinical symptoms (98). CMV pp65 antigenemia assays and the amplification of CMV DNA are currently the most used laboratory techniques for the detection of CMV infection (99-101). CMV pp65 antigenemia assays detect CMV pp65 antigens. Furthermore, PCR is performed to detect CMV DNA viral load (102). Bhatia et al (99) demonstrated that the sensitivity and specificity of the pp65 antigenemia assay were sufficient to use for the early diagnosis of CMV infection. The pp65 antigen is present in neutrophils and has a semi-quantitative association with CMV virus replication. Since the pp65 antigenemia value usually significantly increases during the first week of CMV treatment, the assay results over this period must be taken seriously (103). This method of detection is simple, easy to implement and requires inexpensive equipment. However, in the absence of standard values, the results may be affected by subjective factors (103). In addition, the 
requirements for counting neutrophils are high (104). Despite its low specificity, quantitative DNA-detection techniques have an observable sensitivity and can demonstrate patient prognosis by measuring viral load (99). However, since the results of PCR are affected by the type of specimen used, only plasma or whole blood should be selected for serial viral load testing $(105,106)$. In addition, to differentially diagnose patients with CMV-mediated pneumonia and pulmonary shedding, the quantification of CMV DNA load in bronchoalveolar lavage may be necessary $(107,108)$. Furthermore, the pp67 assay may determine advanced L-mRNA and reflect active HCMV infection, which makes it an effective method for monitoring CMV infection (109).

\section{HCMV infection prophylaxis}

HCMV prophylaxis. CMV prophylaxis is mainly aimed at patients with high-risk CMV infection following allo-HSCT (110). Patients with a high risk of CMV include those that are anti-CMV positive following transplantation, those receiving transplants from unrelated donors, those with donor HLA incompatibility and those receiving $\mathrm{T}$ lymphatic transplantation (111). Preventive measures include donor selection, blood product handling and the application of antiviral drugs (112).

Choice of donors and handling blood products. If both donors and recipients are CMV-IgG negative, recipients are less likely to develop CMV infection following allo-HSCT (13). Thus, for CMV-IgG negative recipients, priority should be given to CMV-IgG negative donors (13). The risk of CMV infection and CMV disease in patients with this combination of donor and recipient serotypes is significantly lower compared with patients demonstrating other serotype combinations (113). The main route of CMV infection is blood transfusion (114). However, Boeckh and Ljungman (13) recommended that if the donor and recipient match at HLA-A, HLA-B or HLA-DR sites, but are seropositive, the matching donor is preferred. In addition, age and blood type should also be taken into consideration when selecting suitable donors (43).

A previous study revealed that blood products obtained after leukocyte depletion effectively decrease the incidence of CMV infection (115). Vamvakas (113) reported that CMV seronegative blood components should be selected over white blood cell reduced blood components to effectively prevent CMV infection. The removal of leukocytes from blood products primarily occurs through filtration, decreasing CMV infection via transfusion. Traditionally, this process is used to screen CMV seronegative blood products and prevent CMV infection (115). However, this screening technique is difficult as it requires increased manpower and material resources (115). In addition, due to the high incidence of CMV infection in certain territories, it may be difficult to obtain CMV seronegative blood products (115).

Application of immuimmunoglobulins (IVIG). The role of IVIG in preventing CMV infection is controversial. Previous studies have demonstrated that IVIG serves no preventive function in CMV diseases and may also cause other serious complications, such as interstitial pneumonia (58,116-118).
In addition, Malagola et al (119) affirmed the clinical therapeutic effect, safety and tolerance of anti-CMV specific immunoglobulins, such as Megalotect. Furthermore, HCMV immunoglobulin has been approved for use in high-risk lung transplant recipients by the Food and Drug Association of the United States (120). Notably, although decreasing immunosuppression to the greatest extent possible is crucial, caution must be used when considering IVIG.

Application of antiviral drugs. The antiviral drugs currently administered to prevent CMV infection include ganciclovir, valganciclovir, foscarnet and cidofovir (Table I). However, the use of antiviral drugs as preventive treatment remains controversial. A recent retrospective study evaluated the effectiveness of antiviral drug administration for the prevention of CMV, the results of which revealed that the regimen was only partially effective (121). An additional prospective study compared the use of valganciclovir with a placebo. The results demonstrated that whilst valganciclovir prophylaxis was effective in decreasing CMV reactivation, it did not decrease CMV infection or mortality, indicating that its affect was not superior when compared with preemptive treatment (122). Thus, due to the disadvantages and adverse drug reactions associated with antiviral drugs, including bone marrow suppression, the majority of HSCT recipients receive preemptive treatment rather than prophylaxis (123).

Vaccine development. The development of safe and effective vaccines for CMV has been the focus of recent medical research. As such, there are currently several vaccines under development (124-127). Adjuvant recombinant protein vaccines, which comprise envelope glycoprotein and DNA plasmid, peptide-based vaccines, vectored vaccines and peptide vaccines are currently used against CMV (125). Among those proposed, a specific bivalent DNA vaccine, named ASP0113, is the most studied. However, phase two clinical trials have indicated that whilst the vaccine demonstrates certain antiviral effects, its immunogenicity is not statistically significant (128). Despite these results, phase three clinical trials are currently underway (126). In addition, another vaccine derived from soluble recombinant glycoprotein B $(\mathrm{gB})$ with the adjuvant MF59 and CMV monoclonal is being developed (127). In conclusion, the application of antiviral vaccines requires additional research and development.

\section{Treatment of HCMV infection}

Preemptive therapy. Preemptive treatment refers to immediate antiviral administration when CMV antigenemia or viremia first occurs following transplantation. Recently, the application of preemptive treatment has significantly decreased the incidence and mortality of CMV-related diseases following allo-HSCT (129). In addition, the length of treatment required for infection has been shortened, and the incidence of adverse reactions has improved (130). Thus, the success of preemptive treatment primarily depends on the sensitive detection of CMV antigenemia (13). If treatment is performed before detecting the virus, some patients may be treated unnecessarily. Any adverse reactions because of drug administration may therefore increase the probability of infection by other 
Table I. Types and properties of standard therapies in prophylaxis and preemptive therapy of CMV infection.

\begin{tabular}{|c|c|c|c|c|}
\hline Drug & Properties & Administration route & Side effects & (Refs.) \\
\hline Ganciclovir & $\begin{array}{l}\text { Inhibits virus replication by } \\
\text { interfering with the action of viral } \\
\text { DNA polymerase }\end{array}$ & Intravenous & $\begin{array}{l}\text { Myelosuppressive effect, } \\
\text { fever, rash, diarrhea }\end{array}$ & $(135,140,143)$ \\
\hline Foscarnet & $\begin{array}{l}\text { Pyrophosphate analog, selective } \\
\text { inhibition of pyrophosphate binding } \\
\text { sites at CMV DNA polymerase }\end{array}$ & Intravenous & $\begin{array}{l}\text { Renal toxicity, neurotoxic } \\
\text { effects, anemia, headache, } \\
\text { Nausea; can cause a fixed } \\
\text { drug reaction on the penis }\end{array}$ & (149) \\
\hline CDV & $\begin{array}{l}\text { Nucleotide analog, is converted to } \\
\text { the active diphosphoryl form by the } \\
\text { host kinases, and CDV disphosphate } \\
\text { acts as a competitive inhibitor of the } \\
\text { viral CMV DNA polymerase, } \\
\text { causing premature chain termination } \\
\text { of viral DNA synthesis }\end{array}$ & Intravenous & Nephrotoxic effects & $(145,149)$ \\
\hline Valganciclovir & Prodrug of ganciclovir & Oral & $\begin{array}{l}\text { Gastrointestinal toxicity, } \\
\text { renal toxicity }\end{array}$ & $(135)$ \\
\hline Letermovir & $\begin{array}{l}\text { Suppresses the CMV-terminase } \\
\text { complex }\end{array}$ & $\begin{array}{l}\text { Intravenous or } \\
\text { oral }\end{array}$ & Prone to drug resistance & $(150)$ \\
\hline
\end{tabular}

CMV, cytomegalovirus; CDV, cidofovir.

bacterial or fungal agents (13). In addition, receiving treatment too late may also affect the antiviral response of patients (131). With use of the CMV pp65 antigen test or PCR, preemptive treatment can be undertaken at a targeted viral load (89). The target viral load varies according to the risk of developing CMV-related diseases and current immunosuppression (132). Drugs currently used for preemptive treatment include ganciclovir, valganciclovir, foscarnet and cidofovir (Table I). Under normal circumstances, preemptive treatment should be maintained until the relevant symptoms are resolved and the CMV serum test is negative (89). If the patients' initial viral load or pp65 antigenemia assay is positive, treatment is maintained until the PCR/pp65 antigenemia assay turns negative. Subsequently, patients should receive maintenance treatment for a varying period (89). The length of maintenance treatment varies from 0-6 weeks depending on factors such as the patients' sensitivity to treatment, drug side effects and the risk of relapse (133).

Most transplant centers worldwide use ganciclovir as the drug of choice for early treatment (134). As an inhibitor of DNA polymerase, ganciclovir inhibits the replication of viral DNA in vivo to prevent viral infection $(112,135)$. Winston et al (136) revealed that when administering ganciclovir prior to or following allo-HSCT, the incidence rate and severity of CMV infection decreases, despite the suppression of bone narrow function. Similar results have been demonstrated in previous studies $(64,137,138)$. The myelosuppressive effect of ganciclovir may be improved by administering granulocyte-colony stimulating factor (G-CSF) alone or in combination with anti-CMV immunoglobulins $(139,140)$. However, ganciclovir is inefficient in treating interstitial pneumonia following transplantation (141).
As the antiviral immunity of patients differs before and after 100 days of transplantation, the corresponding preemptive treatment regimens also differ (142). According to guidelines (142), preemptive treatment within 100 days after transplantation is suitable for patients who have a high risk of CMV infection following autologous stem cell transplantation, and for patients receiving allogeneic stem cell transplantation who have tested positive for CMV antigenemia or viremia for the first time after transplantation (143). The preferred treatment for these patients is inducive intravenous $5 \mathrm{mg} / \mathrm{kg}^{-1} / \mathrm{d}^{-1}$ ganciclovir administered twice a day for 7-14 days, with maintenance therapy once a day until two consecutive tests are negative. In addition, preemptive treatment after 100 days of transplantation is suitable for various patients who achieve two consecutive CMV viremia results or PCR positive tests, including those receiving allogeneic hematopoietic stem cell transplants, GVHD patients receiving steroid therapy or patients receiving CMV antiviral therapy within 100 days of transplantation (131). Due to the myelosuppressive effect of ganciclovir, previous studies have suggested decreasing its dose to a degree that does not change the antiviral effect $(89,144)$. According to a recent study, the dosage should be adjusted based on viral load and that low-dose ganciclovir administered at the beginning of preemptive treatment may be safe and feasible (145). It may also greatly improve the side effects of treatment (89).

Valganciclovir is a prodrug of ganciclovir and demonstrates a good oral bioavailability. A previous study has demonstrated that the blood exposure level of ganciclovir after oral valciclovir administration is higher than intravenous ganciclovir (146). Oral administration is also more convenient and avoids related infections caused by intravenous administration. In addition, 
due to its myelotoxicity and similar side effects to ganciclovir, close monitoring of patients during treatment is required (147).

Furthermore, a randomized controlled trial revealed that foscarnet demonstrated similar effects to ganciclovir but without granulocytopenia, making it suitable for patients exhibiting bone marrow suppression (148). The main adverse reaction following foscarnet administration is electrolyte disturbance; however, this can be easily corrected by intravenous fluid replacement (115).

An additional drug used in preemptive treatment is cidofovir. The pharmacokinetic characteristics of cidofovir require its administration once a week (149). Although its main side effect is renal toxicity, this can be reduced by receiving hydration and probenecid (115). Cidofovir is often administrated when ganciclovir or foscarnet treatment has been ineffective or if the patient demonstrates intolerance (149).

Letermovir (LET) is a novel antiviral drug that suppresses the CMV-terminase complex instead of CMV deoxyribonucleic acid polymerase (150). It can significantly decrease the incidence of CMV infection with few side effects and demonstrates no cross-resistance with other CMV antivirals (150). LET is available both orally and intravenously at 480 and $240 \mathrm{mg}$ dosages, and was approved for use in CMV infection prophylaxis in CMV-seropositive recipients of allogeneic HSCT over the age of 18 in 2017 (151). Previous studies have demonstrated that LET resistance is primarily a result of mutations in the CMV UL56 gene $(152,153)$.

Recently, clinical trials assessing the effectiveness and safety of novel drugs against CMV have been performed or are currently underway (Table II).

Brincidofovir is an orally administered drug that is a bioavailable lipid conjugate of cidofovir (154). Its antiviral effect has been confirmed both in vivo and in vitro (155-157). It has demonstrated a broad spectrum of effects on several viruses, including herpes virus, polyoma virus, adenovirus, papilloma virus and smallpox virus $(158,159)$. The long half-life of brincidofovir and the absence of nephrotoxicity also makes it a desirable candidate for anti-CMV treatment (160-164). However, Marty et al (165) indicated that brincidofovir may be associated with gastrointestinal reactions following administration (165). Based on the existing research currently available, a complete evaluation cannot be made for the clinical application of brincidofovir.

Maribavir is a novel antiviral drug that has recently been developed (84). Despite potentially causing gastrointestinal toxicity, it can be administered orally without the adverse effects of nephrotoxicity and myelosuppression (166). Papanicolaou et al (166) reported that $400 \mathrm{mg}$ maribavir administered twice daily can achieve similar effects to valganciclovir for the treatment of CMV viremia. However, undesirable results were obtained during maribavir phase two clinical trials (167). This negative result may have occurred due to many reasons, such as insufficient dose of maribavir (minimum dose was $100 \mathrm{mg}$ twice daily), exclusion of high-risk groups, high sensitivity of PCR and low CMV-related diseases morbidty in the control group (168). Clinical data regarding the use of maribavir as treatment for refractory or drug resistant CMV have emerged (158,169-171); however, additional studies assessing maribavir administration for transplant recipients are required $(158,169-171)$. 
Table III. CMV-specific T cell therapy clinical trials.

\begin{tabular}{|c|c|c|c|c|c|c|}
\hline Year & $\begin{array}{l}\text { Type of } \\
\text { T cell } \\
\text { selection }\end{array}$ & $\begin{array}{l}\text { Number of } \\
\text { patients } \\
\text { enrolled }\end{array}$ & $\begin{array}{l}\text { Presentation of } \\
\text { antigen }\end{array}$ & CMV outcome & GVHD status & (Refs.) \\
\hline 1995 & $\begin{array}{l}\text { Ex vivo } \\
\text { expansion }\end{array}$ & 14 & $\begin{array}{l}\text { Dendritic cells with } \\
\text { CMV-infected } \\
\text { fibroblasts; only } \\
\text { CD8 clonal population } \\
\text { infused }\end{array}$ & 14 cleared CMV & $\begin{array}{l}3 \text { developed } \\
\text { grade I/II aGVHD } \\
\text { (using steroids) }\end{array}$ & $(176)$ \\
\hline 2002 & $\begin{array}{l}\text { Ex vivo } \\
\text { expansion }\end{array}$ & 7 & $\begin{array}{l}\text { CMV lysate and } \\
\text { peptide mixes of pp65 }\end{array}$ & $\begin{array}{l}1 \text { with persistent CMV } \\
\text { viremia, } 1 \text { with reactivation } \\
\text { after using steroids, } 6 \text { with } \\
\text { CMV-specific T cell } \\
\text { expansion }\end{array}$ & None & $(190)$ \\
\hline 2003 & $\begin{array}{l}\text { Ex vivo } \\
\text { expansion }\end{array}$ & 16 & $\begin{array}{l}\text { Dendritic cells with } \\
\text { CMV-infected } \\
\text { fibroblasts }\end{array}$ & $\begin{array}{l}2 \text { developed } \mathrm{CMV} \\
\text { reactivation, } 8 \text { cleared } \\
\text { CMV with antiviral } \\
\text { treatment }\end{array}$ & $\begin{array}{l}3 \text { with grade I } \\
\text { aGVHD }\end{array}$ & $(178)$ \\
\hline 2005 & $\begin{array}{l}\text { Ex vivo } \\
\text { expansion }\end{array}$ & 25 & $\begin{array}{l}\text { CMV antigen; only } \\
\text { CD4 clonal population } \\
\text { infused }\end{array}$ & $\begin{array}{l}7 \text { developed } \mathrm{CMV} \\
\text { reactivation, } 5 \text { had CMV } \\
\text { diseases, } 2 \text { died due to CMV }\end{array}$ & 1 with GVHD & (191) \\
\hline 2007 & $\begin{array}{l}\text { Ex vivo } \\
\text { expansion }\end{array}$ & 9 & $\begin{array}{l}\text { Dendritic cells with } \\
\text { peptide mix (pp65) }\end{array}$ & $\begin{array}{l}2 \text { developed } \mathrm{CMV} \\
\text { reactivation, with no need } \\
\text { of treatment }\end{array}$ & $\begin{array}{l}3 \text { developed grade } \\
\text { III aGVHD, } 2 \text { of } \\
\text { them died; } 2 \text { with } \\
\text { cGVHD }\end{array}$ & $(188)$ \\
\hline 2010 & $\begin{array}{l}\text { IFN- } \gamma \\
\text { capture }\end{array}$ & 18 & pp65 protein & $\begin{array}{l}4 \text { died associated with CMV, } \\
15 \text { developed ex vivo } \\
\text { expansion }\end{array}$ & 1 with GVHD & $(175)$ \\
\hline 2011 & $\begin{array}{l}\text { IFN- } \gamma \\
\text { capture }\end{array}$ & 18 & Peptide mixes of pp65 & 11 with reactivation & $\begin{array}{l}3 \text { with grade I } \\
\text { aGVHD, } 3 \text { with } \\
\text { grade II/III } \\
\text { aGVHD, } 3 \text { with } \\
\text { cGVHD }\end{array}$ & $(187)$ \\
\hline 2011 & $\begin{array}{l}\text { Streptamer- } \\
\text { selection }\end{array}$ & 2 & $\begin{array}{l}\text { PBMCs with } \\
\text { pp65-HLA beads }\end{array}$ & All cleared CMV & None & (187) \\
\hline 2012 & $\begin{array}{l}\text { Ex vivo } \\
\text { expansion }\end{array}$ & 7 & $\begin{array}{l}\text { Dendritic cells with } \\
\text { peptide mixes } \\
(\text { pp65, IE } 1)\end{array}$ & $\begin{array}{l}4 \text { cleared CMV, } 2 \text { with } \\
\text { reactivation, } 1 \text { with transient } \\
\text { increase in CMV PCR }\end{array}$ & None & (184) \\
\hline 2015 & $\begin{array}{l}\text { Ex vivo } \\
\text { expression }\end{array}$ & 16 & $\begin{array}{l}\text { Dendritic cells with } \\
\text { peptide mix (pp65) }\end{array}$ & 14 cleated CMV & None & $(185)$ \\
\hline 2017 & $\begin{array}{l}\text { Ex vivo } \\
\text { expression }\end{array}$ & 37 & $\begin{array}{l}\text { PBMCs pulsed with } \\
\text { pepmix spanning a } \\
\text { variety of antigens }\end{array}$ & 6 with CR, 10 PR & $\begin{array}{l}5 \text { with grade } \mathrm{I} / \mathrm{II} \\
\text { aGVHD, } 1 \text { with } \\
\text { grade III }\end{array}$ & $(181)$ \\
\hline 2018 & $\begin{array}{l}\text { CliniMACS } \\
\text { Prodigy } \\
\text { Cytokine } \\
\text { Capture } \\
\text { System }\end{array}$ & 3 & $\begin{array}{l}\text { Virus-specific T-cell } \\
\text { separation (CMV pp65 } \\
\text { pepTivator) }\end{array}$ & $\begin{array}{l}2 \text { cleared CMV, } 1 \text { with } \\
\text { upload of CMV }\end{array}$ & None & $(182)$ \\
\hline
\end{tabular}

CMV, cytomegalovirus; GVHD, graft vs. host disease; IFN, interferon; pp65, phosphoprotein 65; IE, immediate early protein; PBMCs, peripheral blood mononuclear cells; CR, complete response; PR, partial response.

Treatment of refractory CMV infection. Refractory CMV infection occurs when CMV antigenemia or DNAemia remains positive, or the CMV DNA copy number increases or remains unchanged after 14 days of regular antiviral 
treatment. When suspected resistance occurs, blood samples should be obtained from patients and sent for the phenotypic testing of resistance genes (1). In addition, certain antiviral drugs, including foscarnet sodium, should be replaced in the case of ganciclovir resistance. Ganciclovir administered in combination with phosphonate sodium is a method. The dose of ganciclovir may be occasionally increased to $15 \mathrm{mg} / \mathrm{kg}^{-1} / \mathrm{d}^{-1}$, with G-CSF administered as a supportive treatment (13). Avery et al (172) demonstrated that the administration of oral maribavir may be beneficial for the treatment of refractory or resistant $\mathrm{CMV}$ infection. In addition, several case reports assessing the antimalarial drug, artesunate, and the novel anti-rheumatic drug, leflunomide, revealed that each agent successfully treated refractory CMV infections that were resistant to multiple antiviral drugs $(173,174)$.

Cellular immunotherapy. The restoration of the CMV-specific CTL response in patients receiving transplantation is indispensable (175). Reusser et al (49) assessed the transfer of CMV-specific CD8 ${ }^{+}$T cells for the first time in 1991 (49). Since then, many studies have done the same. Walter et al (176) selected 14 patients with CMV-specific CTL deficiency following allo-HSCT and applied CTL clones as treatment. The results confirmed the safety and efficiency of this immunotherapeutic technique (176). In a phase two clinical trial performed in 2013, Blyth et al (177) revealed that the adoptive transfer of CMV-specific CTL was exceedingly beneficial for the antiviral response exhibited by patients, the inhibition of virus replication and the spread of infection. Furthermore, Peggs et al (178) treated 16 patients with CMV infection following allo-HSCT with CMV-CTL. The results revealed that $50 \%$ of patients achieved negative CMV DNA without antiviral treatment (178). In a phase I/IIa trial, Neuenhahn et al (179) reported that the adoptive transfer of stem cells from a donor or third-party donor was associated with the reconstitution of CMV-specific T-cells in transplant recipients. In addition, the first application of virus specific T-cell transfer in Turkey exerted a degree of control over CMV replication (176). However, antiviral drugs may be administered in combination due to their lack of effect on CMV specific IgG (180).

The application of CMV-CTL can speed up the immune reconstruction of patients following allo-HSCT $(181,182)$, effectively suppressing CMV replication whilst decreasing the use of antiviral drugs and their accompanying adverse reactions (183). It may therefore be an ideal replacement for antiviral drugs in the future $(184,185)$. The occurrence of GVHD (both acute and chronic) is a significant concern in initial trials that utilize unmanipulated donor products (183). According to previous studies, these concerns can be eliminated with the development of technologies that select and expand specific T cells $(179,186)$. Recently, the rates of GVHD following cell therapy have not exceeded those expected for patients post-HSCT $(179,186)$. Almost all patients who develop GVHD following treatment do so as the result of other high-risk factors, including history of chronic or acute GVHD, subtherapeutic immunosuppression or receiving prior T cell-replete grafts (187-189) (Table III). However, there are still several challenges for the clinical application of this method (190). Although a study has suggested that G-CSF can be used for stimulation (191), it is unknown how to practically prepare T cells for this treatment (192). In addition, there is no uniform standard for T-cell subsets that are optimal for anti-CMV treatment (186). Thus, this method needs to be improved through subsequent research.

Mesenchymal stem cells (MSCs) are one of the most common adult stem cells, originating from non-hematopoietic stem cells isolated from bone marrow (193). MSCs participate in the formation of the bone marrow hematopoietic microenvironment and provide significant support for the proliferation and differentiation of hematopoietic stem cells (194). MSCs can also support hematopoietic reconstitution by cell-cell contact and the secretion of cytokines to promote the shift from Th2 to Th1 phenotypes, increasing the expression of $\mathrm{T}$ regulatory cells to regulate the immune system (195). MSCs have been used in the treatment of GVHD and have wide application prospects (196). However, research on MSCs has primarily focused on its effect on allogeneic T cells (197). Thus, whether virus-specific T cells have the same effect is yet to be fully elucidated. In addition, little is known about how MSCs affect CTLs and the conversion of memory and effector T-cell subgroups in CMV-CTL. In our previous study, it was demonstrated that MSCs inhibit the proliferation of allogeneic $\mathrm{CD}^{+} \mathrm{T}$ cells and $\mathrm{CMV}$-specific T cells in vitro (198). However, there is insufficient evidence on whether its molecular mechanism of action and T-cell immune function are affected.

\section{Leukemia relapse following allo-HSCT}

Although CMV infection can cause high mortality following transplantation, Elmaagacli et al (199) revealed that patients with acute myeloid leukemia (AML) demonstrating donor and recipient CMV seropositivity or early or late post-transplantation CMV antigenemia have a decreased risk of relapse. This may be due to the apoptosis of AML cells following HCMV reactivation (200-203). However, current conclusions and related mechanisms require further research.

\section{Conclusions}

With the continuous advancement of transplantation technology, an increased number of patients with hematological tumors are undergoing HSCT. Correspondingly, the number of CMV infections following transplantation is also increasing. Antiviral treatment still occupies the mainstream position in the prevention and treatment of CMV, and drugs currently used for prophylaxis and preemptive treatment include ganciclovir, valganciclovir, foscarnet and cidofovir. Although the application of post-transplantation CMV infection antiviral prophylaxis and preemptive therapy has significantly decreased the risk of post-transplant CMV infection and disease, adverse reactions are commonplace. Thus, other methods that decrease the incidence of CMV infection and disease following transplantation are urgently required. Notable advancements have been established in recent years, including the elucidation of novel drugs, the adoptive transfer of CMV-specific CTLs and the application of MSCs. Although the effectiveness of these novel methods has not yet been determined, it is believed that with the progress of research, the prophylaxis and treatment 
of CMV infection following transplantation will further improved.

\section{Acknowledgements}

Not applicable.

\section{Funding}

The present review was supported by the Natural Science Foundation of Jiangsu Province (grant no. BK20150639), the Key Medical of Jiangsu Province (grant no. ZDXKB2016020), the Six Talent Peaks Project in Jiangsu Province (grant no. WSW-033) and the Innovative and entrepreneurial doctors of Jiangsu province.

\section{Availability of data and materials}

Not applicable.

\section{Authors' contributions}

$\mathrm{XZ}, \mathrm{NJ}$ and $\mathrm{BC}$ were responsible for confirming the topic, and collecting and analyzing the data. XZ designed and drafted the initial manuscript, and edited the figure legends and tables. All authors have read and approved the final manuscript.

\section{Ethics approval and consent to participate}

Not applicable.

\section{Patient consent for publication}

Not applicable.

\section{Competing interests}

The authors declare that they have no competing interests.

\section{References}

1. Ljungman P, de la Camara R, Robin C, Crocchiolo R, Einsele H, Hill JA, Hubacek P, Navarro D, Cordonnier C and Ward KN; 2017 European Conference on Infections in Leukaemia group: Guidelines for the management of cytomegalovirus infection in patients with haematological malignancies and after stem cell transplantation from the 2017 European Conference on Infections in Leukaemia (ECIL 7). Lancet Infect Dis 19: e260-e272, 2019.

2. Gyurkocza B, Rezvani A and Storb RF: Allogeneic hematopoietic cell transplantation: The state of the art. Expert Rev Hematol 3: 285-299, 2010.

3. Gratwohl A, Baldomero H, Aljurf M, Pasquini MC, Bouzas LF, Yoshimi A, Szer J, Lipton J, Schwendener A, Gratwohl M, et al: Hematopoietic stem cell transplantation: A global perspective. JAMA 303: 1617-1624, 2010.

4. Borchers S, Luther S, Lips U, Hahn N, Kontsendorn J, Stadler M, Buchholz S, Diedrich H, Eder M, Koehl U, et al: Tetramer monitoring to assess risk factors for recurrent cytomegalovirus reactivation and reconstitution of antiviral immunity post allogeneic hematopoietic stem cell transplantation. Transpl Infect Dis 13: 222-236, 2011.

5. Moss P and Rickinson A: Cellular immunotherapy for viral infection after HSC transplantation. Nat Rev Immunol 5: 9-20, 2005.
6. Haidar G and Singh N: Viral infections in solid organ transplant recipients: Novel updates and a review of the classics. Curr Opin Infect Dis 30: 579-588, 2017.

7. Enders G, Daiminger A, Lindemann L, Knotek F, Bäder U, Exler S and Enders M: Cytomegalovirus (CMV) seroprevalence in pregnant women, bone marrow donors and adolescents in Germany, 1996-2010. Med Microbiol Immunol 201: 303-309, 2012.

8. Ouédraogo AS, Yaméogo JT, Poda GEA, Kientega Y and Ouédraogo Traore R: Prevalence of anti-CMV antibodies in blood donors in Ouagadougou (Burkina Faso). Med Sante Trop 22: 107-109, 2012.

9. Revello MG, Vauloup-Fellous C, Grangeot-Keros L, van Helden J, Dickstein Y, Lipkin I, Mühlbacher A and Lazzarotto T: Clinical evaluation of new automated cytomegalovirus $\operatorname{IgM}$ and $\operatorname{IgG}$ assays for the Elecsys $\left({ }^{\circledR}\right)$ analyser platform. Eur J Clin Microbiol Infect Dis 31: 3331-3339, 2012.

10. Strand KM, Odland ML, Iversen AC, Nordb $\emptyset$ SA, Vik T and Austgulen R: Cytomegalovirus antibody status at 17-18 weeks of gestation and pre-eclampsia: A case-control study of pregnant women in Norway. BJOG 119: 1316-1323, 2012.

11. Amsler L, Verweij M and DeFilippis VR: The tiers and dimensions of evasion of the type I interferon response by human cytomegalovirus. J Mol Biol 425: 4857-4871, 2013.

12. Siegel RL, Miller KD and Jemal A: Cancer statistics, 2020. CA Cancer J Clin 70: 7-30, 2013.

13. Boeckh M and Ljungman P: How we treat cytomegalovirus in hematopoietic cell transplant recipients. Blood 113: 5711-5719, 2009.

14. Bankier AT, Beck S, Bohni R, Brown CM, Cerny R, Chee MS, Hutchison CA III, Kouzarides T, Martignetti JA, Preddie E, et al: The DNA sequence of the human cytomegalovirus genome. DNA Seq 2: 1-12, 1991.

15. Murphy E and Shenk T: Human cytomegalovirus genome. Curr Top Microbiol Immunol 325: 1-19, 2008.

16. Scherer M, Schilling EM and Stamminger T: The human CMV IE1 protein: An offender of PML NUCLEAR BOdies. Adv Anat Embryol Cell Biol 223: 77-94, 2017.

17. Fox HL, Dembowski JA and DeLuca NA: A herpesviral immediate early protein promotes transcription elongation of viral transcripts. mBio 8: e00745-17, 2017.

18. Gardner TJ and Tortorella D: Virion glycoprotein-mediated immune evasion by human cytomegalovirus: A sticky virus makes a slick getaway. Microbiol Mol Biol Rev 80: 663-677, 2016.

19. Sezgin E, An P and Winkler CA: Host genetics of cytomegalovirus pathogenesis. Front Genet 10: 616, 2019.

20. Cheung AK, Gottlieb DJ, Plachter B, Pepperl-Klindworth S, Avdic S, Cunningham AL, Abendroth A and Slobedman B: The role of the human cytomegalovirus UL111A gene in downregulating $\mathrm{CD}^{+} \mathrm{T}$-cell recognition of latently infected cells: Implications for virus elimination during latency. Blood 114: 4128-4137, 2009.

21. Slavuljica I, Busche A, Babić M, Mitrović M, Gašparović I, Cekinović D, Markova Car E, Pernjak Pugel E, Ciković A, Lisnić VJ, et al: Recombinant mouse cytomegalovirus expressing a ligand for the NKG2D receptor is attenuated and has improved vaccine properties. J Clin Invest 120: 4532-4545, 2010.

22. Griffiths PD: Burden of disease associated with human cytomegalovirus and prospects for elimination by universal immunisation. Lancet Infect Dis 12: 790-798, 2012.

23. Wilkinson GW, Tomasec P, Stanton RJ, Armstrong M, Prod'homme V, Aicheler R, McSharry BP, Rickards CR, Cochrane D, Llewellyn-Lacey S, et al: Modulation of natural killer cells by human cytomegalovirus. J Clin Virol 41: 206-212, 2008.

24. Fang D and Zhu J: Molecular switches for regulating the differentiation of inflammatory and IL-10-producing anti-inflammatory T-helper cells. Cell Mol Life Sci 77: 289-303, 2020.

25. Zhou L, Chong MM and Littman DR: Plasticity of CD4 ${ }^{+} \mathrm{T}$ cell lineage differentiation. Immunity 30: 646-655, 2009.

26. Opal SM and DePalo VA: Anti-inflammatory cytokines. Chest 117: 1162-1172, 2000.

27. McSharry BP, Avdic S and Slobedman B: Human cytomegalovirus encoded homologs of cytokines, chemokines and their receptors: Roles in immunomodulation. Viruses 4: 2448-2470, 2012 . 
28. Barel MT, Ressing M, Pizzato N, van Leeuwen D, Le Bouteiller P, Lenfant $F$ and Wiertz EJ: Human cytomegalovirus-encoded US2 differentially affects surface expression of MHC class I locus products and targets membrane-bound, but not soluble HLA-G1 for degradation. J Immunol 171: 6757-6765, 2003.

29. Khan N, Bruton R, Taylor GS, Cobbold M, Jones TR, Rickinson $\mathrm{AB}$ and Moss PA: Identification of cytomegalovirus-specific cytotoxic T lymphocytes in vitro is greatly enhanced by the use of recombinant virus lacking the US2 to US11 region or modified vaccinia virus Ankara expressing individual viral genes. J Virol 79: 2869-2879, 2005.

30. Ciáurriz M, Zabalza A, Beloki L, Mansilla C Pérez-Valderrama E, Lachén M, Bandrés E, Olavarría E and Ramírez N: The immune response to cytomegalovirus in allogeneic hematopoietic stem cell transplant recipients. Cell Mol Life Sci 72: 4049-4062, 2015.

31. Minton K: Viral immunity: How CMV bypasses immune memory. Nat Rev Immunol 10: 288, 2010.

32. Reddehase MJ and Lemmermann NAW: Cellular reservoirs of latent cytomegaloviruses. Med Microbiol Immunol 208: 391-403, 2019

33. Sinzger C, Digel M and Jahn G: Cytomegalovirus cell tropism. Curr Top Microbiol Immunol 325: 63-83, 2008.

34. Higdon LE, Trofe-Clark J, Liu S, Margulies KB, Sahoo MK, Blumberg E, Pinsky BA and Maltzman JS Cytomegalovirus-responsive $\mathrm{CD} 8^{+} \mathrm{T}$ cells expand after solid organ transplantation in the absence of CMV disease. Am J Transplant 17: 2045-2054, 2017.

35. Albiero E, Amati E, Baumeister E, Einsele H, Grigoleit GU and Rodeghiero F: Heterogeneity of Specific CD4 ${ }^{+}$and $\mathrm{CD}^{+} \mathrm{T}$ cells stimulated by CMV pp65 and IE1 antigens. J Immunother 39: 329-342, 2016

36. Styczynski J: Who is the patient at risk of CMV recurrence: A review of the current scientific evidence with a focus on hematopoietic cell transplantation. Infect Dis Ther 7: 1-16, 2018.

37. Cho SY, Lee DG and Kim HJ: Cytomegalovirus infections after hematopoietic stem cell transplantation: Current status and future immunotherapy. Int J Mol Sci 20: 2666, 2019.

38. Kim SJ, Varghese TK, Zhang Z, Zhao LC, Thomas G, Hummel $M$ and Abecassis $M$ : Renal ischemia/reperfusion injury activates the enhancer domain of the human cytomegalovirus major immediate early promoter. Am J Transplant 5: $1606-1613,2005$.

39. Kurata K, Yakushijin K, Mizuno I, Gomyo H, Okamura A, Ichikawa H, Sakai R, Mizutani Y, Kakiuchi S, Miyata Y, et al: Early lymphocyte recovery predicts clinical outcome after HSCT with mycophenolate mofetil prophylaxis in the Japanese population. Int J Hematol 108: 58-65, 2018.

40. Theobald SJ, Khailaie S, Meyer-Hermann M, Volk V, Olbrich H Danisch S, Gerasch L, Schneider A, Sinzger C, Schaudien D, et al: Signatures of $\mathrm{T}$ and $\mathrm{B}$ cell development, functional responses and PD-1 upregulation after HCMV latent infections and reactivations in Nod.Rag.Gamma mice humanized with cord blood CD34 ${ }^{+}$cells. Front Immunol 9: 2734, 2018

41. Camargo JF, Wieder ED, Kimble E, Benjamin CL, Kolonias DS, Kwon D, Chen XS and Komanduri KV: Deep functional immunophenotyping predicts risk of cytomegalovirus reactivation after hematopoietic cell transplantation. Blood 133: 867-877, 2019.

42. van Gent R, Metselaar HJ and Kwekkeboom J Immunomodulation by hyperimmunoglobulins after solid organ transplantation: Beyond prevention of viral infection. Transplant Rev (Orlando) 31: 78-86, 2017

43. Prösch S, Wendt CE, Reinke P, Priemer C, Oppert M, Krüger DH, Volk HD and Döcke WD: A novel link between stress and human cytomegalovirus (HCMV) infection: Sympathetic hyperactivity stimulates HCMV activation. Virology 272: 357-365, 2000.

44. Atabani SF, Smith C, Atkinson C, Aldridge RW, Rodriguez-Perálvarez M, Rolando N, Harber M, Jones G, O'Riordan A, Burroughs AK, et al: Cytomegalovirus replication kinetics in solid organ transplant recipients managed by preemptive therapy. Am J Transplant 12: 2457-2464, 2012.

45. Yong MK, Lewin SR and Manuel O: Immune monitoring for CMV in transplantation. Curr Infect Dis Rep 20: 4, 2018.

46. Blyth E, Withers B, Clancy L and Gottlieb D: CMV-specific immune reconstitution following allogeneic stem cell transplantation. Virulence 7: 967-980, 2016.

47. Król L, Stuchlý J, Hubáček P, Keslová P, Sedláček P, Starý J, Hrušák $\mathrm{O}$ and Kalina T: Signature profiles of CMV-specific T-cells in patients with CMV reactivation after hematopoietic SCT. Bone Marrow Transplant 46: 1089-1098, 2011.
48. Lilleri D, Gerna G,Zelini P, Chiesa A, Rognoni V, Mastronuzzi A, Giorgiani G, Zecca M and Locatelli F: Monitoring of human cytomegalovirus and virus-specific T-cell response in young patients receiving allogeneic hematopoietic stem cell transplantation. PLoS One 7: e41648, 2012.

49. Reusser P, Riddell SR, Meyers JD and Greenberg PD: Cytotoxic T-lymphocyte response to cytomegalovirus after human allogeneic bone marrow transplantation: Pattern of recovery and correlation with cytomegalovirus infection and disease. Blood 78: 1373-1380, 1991.

50. Ogonek J, Varanasi P, Luther S, Schweier P, Kühnau W, Göhring G, Dammann E, Stadler M, Ganser A, Borchers S, et al: Possible impact of cytomegalovirus-specific $\mathrm{CD}^{+} \mathrm{T}$ cells on immune reconstitution and conversion to complete donor chimerism after allogeneic stem cell transplantation. Biol Blood Marrow Transplant 23: 1046-1053, 2017.

51. Hill GR, Kuns RD, Raffelt NC, Don AL, Olver SD, Markey KA, Wilson YA, Tocker J, Alexander WS, Clouston AD, et al: SOCS3 regulates graft-versus-host disease. Blood 116: 287-296, 2010.

52. Alexander WS: Suppressors of cytokine signalling (SOCS) in the immune system. Nat Rev Immunol 2: 410-416, 2002.

53. Lee TH, Lee JY, Park S, Shin SH, Yahng SA, Yoon JH, Lee SE, Cho BS, Kim YJ, Lee S, et al: Expression of SOCS1 and SOCS3 genes in human graft-versus-host disease after allogeneic hematopoietic stem cell transplantation. Blood Res 48: 16-23, 2013.

54. Shin SH, Lee JY, Lee TH, Park SH, Yahng SA, Yoon JH, Lee SE, Cho BS, Lee DG, Kim YJ, et al: SOCS1 and SOCS3 are expressed in mononuclear cells in human cytomegalovirus viremia after allogeneic hematopoietic stem cell transplantation. Blood Res 50: 40-45, 2015.

55. Meyers JD, Flournoy N and Thomas ED: Risk factors for cytomegalovirus infection after human marrow transplantation. J Infect Dis 153: 478-488, 1986.

56. Kuo HT, Ye X, Sampaio MS, Reddy P and Bunnapradist S: Cytomegalovirus serostatus pairing and deceased donor kidney transplant outcomes in adult recipients with antiviral prophylaxis. Transplantation 90: 1091-1098, 2010.

57. Nichols WG, Corey L, Gooley T, Davis C and Boeckh M: High risk of death due to bacterial and fungal infection among cytomegalovirus (CMV)-seronegative recipients of stem cell transplants from seropositive donors: Evidence for indirect effects of primary CMV infection. J Infect Dis 185: 273-282, 2002.

58. Schnitzler MA, Woodward RS, Brennan DC, Spitznagel EL, Dunagan WC and Bailey TC: Impact of cytomegalovirus serology on graft survival in living related kidney transplantation: Implications for donor selection. Surgery 121: 563-568, 1997.

59. Gerstenkorn C, Balupuri S, Mohamed MA, Manas DM, Ali S, Kirby J and Talbot D: The impact of cytomegalovirus serology for 7-year graft survival in cadaveric kidney transplantation-the Newcastle experience. Transpl Int 13 (Suppl 1): S372-S374, 2000.

60. Harvala H, Stewart C, Muller K, Burns S, Marson L, MacGilchrist A and Johannessen I: High risk of cytomegalovirus infection following solid organ transplantation despite prophylactic therapy. J Med Virol 85: 893-898, 2013.

61. Amouzegar A, Dey BR and Spitzer TR: Peripheral blood or bone marrow stem cells? Practical considerations in hematopoietic stem cell transplantation. Transfus Med Rev 33: 43-50, 2019.

62. Trenschel R, Ross S, Hüsing J, Ottinger H, Elmaagacli A, Roggendorf M, Schaefer UW and Runde V: Reduced risk of persisting cytomegalovirus pp65 antigenemia and cytomegalovirus interstitial pneumonia following allogeneic PBSCT. Bone Marrow Transplant 25: 665-672, 2000.

63. Uppuluri R, Subburaj D, Jayaraman D, Swaminathan VV, Mullanfiroze K, Vaidhyanathan L and Raj R: Cytomegalovirus reactivation posthematopoietic stem cell transplantation (HSCT) and type of graft: A step toward rationalizing CMV testing and positively impacting the economics of HSCT in developing countries. Pediatr Blood Cancer: 64, 2017. doi: 10.1002/pbc. 26639.

64. Boeckh M, Gooley TA, Myerson D, Cunningham T, Schoch G and Bowden RA: Cytomegalovirus pp65 antigenemia-guided early treatment with ganciclovir versus ganciclovir at engraftment after allogeneic marrow transplantation: A randomized double-blind study. Blood 88: 4063-4071, 1996.

65. Gatault P, Al-Hajj S, Noble J, Chevallier E, Piollet M, Forconi C, Gaudy-Graffin C, Thibault G, Miquelestorena-Standley E, Halimi JM, et al: CMV-infected kidney grafts drive the expansion of blood-borne $\mathrm{CMV}$-specific $\mathrm{T}$ cells restricted by shared class I HLA molecules via presentation on donor cells. Am J Transplant 18: 1904-1913, 2018. 
66. Sylwester AW, Mitchell BL, Edgar JB, Taormina C, Pelte C, Ruchti F, Sleath PR, Grabstein KH, Hosken NA, Kern F, et al: Broadly targeted human cytomegalovirus-specific $\mathrm{CD}^{+}$and $\mathrm{CD}^{+} \mathrm{T}$ cells dominate the memory compartments of exposed subjects. J Exp Med 202: 673-685, 2005.

67. Essa S, Pacsa A, Said T, Nampoory MR, Raghupathy R, Johny KV, Al-Nakib W and Al-Mosawy M: Is combined pretransplantation seropositivity of kidney transplant recipients for cytomegalovirus antigens (pp150 and pp28) a predictor for protection against infection? Med Princ Pract 17: 66-70, 2008.

68. Wills MR, Okecha G, Weekes MP, Gandhi MK, Sissons PJ and Carmichael AJ: Identification of naive or antigen-experienced human $\mathrm{CD}^{+} \mathrm{T}$ cells by expression of costimulation and chemokine receptors: Analysis of the human cytomegalovirusspecific $\mathrm{CD}^{+} \mathrm{T}$ cell response. J Immunol 168: 5455-5464, 2002

69. Maecker HT and Maino VC: Analyzing T-cell responses to cytomegalovirus by cytokine flow cytometry. Hum Immunol 65: 493-499, 2004

70. Baumann NS, Welten SPM, Torti N, Pallmer K, Borsa M, Barnstorf I, Oduro JD, Cicin-Sain L and Oxenius A: Early primed KLRG1-CMV-specific T cells determine the size of the inflationary T cell pool. PLoS Pathog 15: e1007785, 2019.

71. Scheinberg P, Melenhorst JJ, Brenchley JM, Hill BJ, Hensel NF, Chattopadhyay PK, Roederer M, Picker LJ, Price DA, Barrett AJ and Douek DC: The transfer of adaptive immunity to CMV during hematopoietic stem cell transplantation is dependent on the specificity and phenotype of CMV-specific T cells in the donor. Blood 114: 5071-5080, 2009.

72. Liu J, Chang YJ, Yan CH, Xu LP, Jiang ZF, Zhang XH, Liu KY and Huang XJ: Poor CMV-specific CD8+ T central memory subset recovery at early stage post-HSCT associates with refractory and recurrent CMV reactivation. J Infect 73: 261-270, 2016.

73. LaMattina JC, Mezrich JD, Hofmann RM, Foley DP, D'Alessandro AM, Sollinger HW and Pirsch JD: Alemtuzumab as compared to alternative contemporary induction regimens. Transpl Int 25: 518-526, 2012.

74. Wang QY, Dong YJ, Liang ZY, Yin Y, Liu W, Xu WL, Sun YH, Han N, Li Y and Ren HY: Clinical analysis for patients with AML treated after Allo-HSCT. Zhongguo Shi Yan Xue Ye Xue Za Zhi 28: 1105-1114, 2020 (In Chinese).

75. Kanter J, Pallardó L, Gavela E, Escudero V, Beltrán S, Morales A, Avila A and Crespo JF: Cytomegalovirus infection renal transplant recipients: Risk factors and outcome. Transplant Proc 41: 2156-2158, 2009.

76. Hosseini-Moghaddam SM, Rotstein C and Husain S: Effects of the intensity of immunosuppressive therapy on outcome of treatment for CMV disease in organ transplant recipients. Am J Transplant 11: 407, 2011.

77. Kobashigawa JA, Miller LW, Russell SD, Ewald GA, Zucker MJ, Goldberg LR, Eisen HJ, Salm K, Tolzman D, Gao J, et al: Tacrolimus with mycophenolate mofetil (MMF) or sirolimus vs. cyclosporine with MMF in cardiac transplant patients: 1-year report. Am J Transplant 6: 1377-1386, 2006.

78. Viganò M, Dengler T, Mattei MF, Poncelet A, Vanhaecke J, Vermes E, Kleinloog R, Li Y, Gezahegen Y and Delgado JF; RAD A2411 Study Investigators: Lower incidence of cytomegalovirus infection with everolimus versus mycophenolate mofetil in de novo cardiac transplant recipients: A randomized, multicenter study. Transpl Infect Dis 12: 23-30, 2010.

79. Axelrod D, Leventhal JR, Gallon LG, Parker MA and Kaufman DB: Reduction of CMV disease with steroid-free immunosuppresssion in simultaneous pancreas-kidney transplant recipients. Am J Transplant 5: 1423-1429, 2005.

80. Ekberg H, Bernasconi C, Nöldeke J, Yussim A, Mjörnstedt L, Erken U, Ketteler M and Navrátil P: Cyclosporine, tacrolimus and sirolimus retain their distinct toxicity profiles despite low doses in the Symphony study. Nephrol Dial Transplant 25: 2004-2010, 2010.

81. Muffly L, Sheehan K, Armstrong R, Jensen K, Tate K, Rezvani AR, Miklos D, Arai S, Shizuru J, Johnston L, et al: Infusion of donor-derived $\mathrm{CD}^{+}$memory $\mathrm{T}$ cells for relapse following allogeneic hematopoietic cell transplantation. Blood Adv 2: 681-690, 2018.

82. Teijaro JR: Cytokine storms in infectious diseases. Semin Immunopathol 39: 501-503, 2017.

83. Miller W, Flynn P, McCullough J, Balfour HH Jr, Goldman A, Haake R, McGlave P, Ramsay N and Kersey J: Cytomegalovirus infection after bone marrow transplantation: An association with acute graft-v-host disease. Blood 67: 1162-1167, 1986.
84. Stern A and Papanicolaou GA: CMV prevention and treatment in transplantation: What's New in 2019. Curr Infect Dis Rep 21: 45, 2019.

85. Murata M, Ikegame K, Morishita Y, Ogawa H, Kaida K, Nakamae H, Ikeda T, Nishida T, Inoue M, Eto T, et al: Low-dose thymoglobulin as second-line treatment for steroid-resistant acute GvHD: An analysis of the JSHCT. Bone Marrow Transplant 52: 252-257, 2017.

86. Lin HC, Han SM, Hwang WL, Chou CW, Chang KH, Shi ZY and Jerry Teng CL: Cytomegalovirus infection and treatment in allogeneic hematopoietic stem cell transplantation: A retrospective study from a single institution in an endemic area. Turk J Haematol 34: 159-166, 2017.

87. Xue H, Hu Y, Feng S, Liu Z and Gao F: Risk factor analysis for cytomegalovirus infection after peripheral blood allogeneic hematopoietic stem cell transplantation. J China Med Univ 48: 417-420, 2019

88. Fuji S, Einsele $\mathrm{H}$ and Kapp M: Cytomegalovirus disease in hematopoietic stem cell transplant patients: Current and future therapeutic options. Curr Opin Infect Dis 30: 372-376, 2017.

89. Park SY, Lee SO, Choi SH, Kim YS, Woo JH, Baek S, Sung H, Kim MN, Kim DY, Lee JH, et al: Efficacy and safety of low-dose ganciclovir preemptive therapy in allogeneic haematopoietic stem cell transplant recipients compared with conventional-dose ganciclovir: A prospective observational study. J Antimicrob Chemother 67: 1486-1492, 2012.

90.Zhu MX, Wan WL, Li HS, Wang J, Wang YF, Hu K and Ke XY: Early immune reconstitution after hematopoietic stem cell transplantation. Beijing Da Xue Xue Bao Yi Xue Ban 48: 515-522, 2016 (In Chinese).

91. Yong MK, Cameron PU, Slavin M, Morrissey CO, Bergin K, Spencer A, Ritchie D, Cheng AC, Samri A, Carcelain G, et al: Identifying cytomegalovirus complications using the quantiferon-CMV assay after allogeneic hematopoietic stem cell transplantation. J Infect Dis 215: 1684-1694, 2017.

92. Wagner-Drouet E, Teschner D, Wolschke C, Janson D, Schäfer-Eckart K, Gärtner J, Mielke S, Schreder M, Kobbe G, Kondakci M, et al: Standardized monitoring of cytomegalovirus-specific immunity can improve risk stratification of recurrent cytomegalovirus reactivation after hematopoietic stem cell transplantation. Haematologica 106: 363-374, 2021

93. El Haddad L, Ariza-Heredia E, Shah DP, Jiang Y, Blanchard T, Ghantoji SS, El Chaer F, El-Haddad D, Prayag A, Nesher L, et al: The ability of a cytomegalovirus ELISPOT assay to predict outcome of low-level CMV reactivation in hematopoietic cell transplant recipients. J Infect Dis 219: 898-907, 2019.

94. Krawczyk A, Ackermann J, Goitowski B, Trenschel R, Ditschkowski M, Timm J, Ottinger H, Beelen DW, Grüner N and Fiedler M: Assessing the risk of CMV reactivation and reconstitution of antiviral immune response post bone marrow transplantation by the QuantiFERON-CMV-assay and real time PCR. J Clin Virol 99-100: 61-66, 2018.

95. Cao K, Marin D, Sekine T, Rondon G, Zhao W, Smith NT, Daher M, Wang Q, Li L, Saliba RM, et al: Donor NKG2C copy number: An independent predictor for CMV reactivation after double cord blood transplantation. Front Immunol 9: 2444, 2018.

96. Albert E, Solano C, Giménez E, Focosi D, Pérez A, Macera L, Piñana JL, Boluda JCH, Maggi F and Navarro D: The kinetics of torque teno virus plasma DNA load shortly after engraftment predicts the risk of high-level CMV DNAemia in allogeneic hematopoietic stem cell transplant recipients. Bone Marrow Transplant 53: 180-187, 2018.

97. Takahashi R, Nakatsukasa H, Shiozawa S and Yoshimura A: SOCS1 is a key molecule that prevents regulatory $\mathrm{T}$ cell plasticity under inflammatory conditions. J Immunol 199: 149-158, 2017

98. Lodding IP, Schultz HH, Jensen JU, Kirkby N, Perch M, Andersen C, Lundgren JD and Iversen M: Cytomegalovirus viral load in bronchoalveolar lavage to diagnose lung transplant associated CMV pneumonia. Transplantation 102: 326-332, 2018.

99. Bhatia J, Shah BV, Mehta AP, Deshmukh M, Sirsat RA and Rodrigues $\mathrm{C}$ : Comparing serology, antigenemia assay and polymerase chain reaction for the diagnosis of cytomegalovirus infection in renal transplant patients. J Assoc Physicians India 52: 297-300, 2004

100. Griscelli F, Barrois M, Chauvin S, Lastere S, Bellet D and Bourhis JH: Quantification of human cytomegalovirus DNA in bone marrow transplant recipients by real-time PCR. J Clin Microbiol 39: 4362-4369, 2001. 
101. Drew WL: Laboratory diagnosis of cytomegalovirus infection and disease in immunocompromised patients. Curr Opin Infect Dis 20: 408-411, 2007.

102. Pollack M, Heugel J, Xie H, Leisenring W, Storek J, Young JA, Kukreja M, Gress R, Tomblyn M and Boeckh M: An international comparison of current strategies to prevent herpesvirus and fungal infections in hematopoietic cell transplant recipients. Biol Blood Marrow Transplant 17: 664-673, 2011.

103. Malouli D, Hansen SG, Nakayasu ES, Marshall EE, Hughes CM, Ventura AB, Gilbride RM, Lewis MS, Xu G, Kreklywich C, et al: Cytomegalovirus pp65 limits dissemination but is dispensable for persistence. J Clin Invest 124: 1928-1944, 2014.

104. Lee H, Park KH, Ryu JH, Choi AR, Yu JH, Lim J, Han K, Kim SI, Yang CW, Chung BH and Oh EJ: Cytomegalovirus (CMV) immune monitoring with ELISPOT and QuantiFERON-CMV assay in seropositive kidney transplant recipients. PLoS One 12 e0189488, 2017

105. Lisboa LF, Asberg A, Kumar D, Pang X, Hartmann A, Preiksaitis JK, Pescovitz MD, Rollag H, Jardine AG and Humar A: The clinical utility of whole blood versus plasma cytomegalovirus viral load assays for monitoring therapeutic response. Transplantation 91: 231-236, 2011.

106. Gerna G, Lilleri D, Caldera D, Furione M, Zenone Bragotti L amd Alessandrino EP: Validation of a DNAemia cutoff for preemptive therapy of cytomegalovirus infection in adult hematopoietic stem cell transplant recipients. Bone Marrow Transplant 41: 873-879, 2008.

107. Boeckh M, Stevens-Ayers T, Travi G, Huang M-L, Cheng GS, Xie H, Leisenring W, Erard V, Seo S, Kimball L, et al: Cytomegalovirus (CMV) DNA quantitation in bronchoalveolar lavage fluid from hematopoietic stem cell transplant recipients with CMV pneumonia. J Infect Dis 215: 1514-1522, 2017.

108. Beam E, Germer JJ, Lahr B, Yao JDC, Limper AH, Binnicker MJ and Razonable RR: Cytomegalovirus (CMV) DNA quantification in bronchoalveolar lavage fluid of immunocompromised patients with CMV pneumonia. Clin Transplant: 32, 2018. doi: $10.1111 /$ ctr.13149.

109. Hebart H, Rudolph T, Loeffler J, Middeldorp J, Ljubicic T, Jahn G and Einsele H: Evaluation of the NucliSens CMV pp67 assay for detection and monitoring of human cytomegalovirus infection after allogeneic stem cell transplantation. Bone Marrow Transplant 30: 181-187, 2002.

110. Rea F, Potena L, Yonan N, Wagner F and Calabrese F: Cytomegalovirus hyper immunoglobulin for CMV prophylaxis in thoracic transplantation. Transplantation 100 (Suppl 3): S19-S26, 2016

111. Kotton CN: CMV: Prevention, diagnosis and therapy. Am J Transplant 13 (Suppl 3): S24-S40, 2013.

112. Griffiths PD: An explanation for posttransplant late-onset disease associated with CMV prophylaxis. Rev Med Virol 29: e2080, 2019

113. Vamvakas EC: Is white blood cell reduction equivalent to antibody screening in preventing transmission of cytomegalovirus by transfusion? A review of the literature and meta-analysis. Transfus Med Rev 19: 181-199, 2005.

114. Bowden RA, Sayers M, Flournoy N, Newton B, Banaji M, Thomas ED and Meyers JD: Cytomegalovirus immune globulin and seronegative blood products to prevent primary cytomegalovirus infection after marrow transplantation. N Engl J Med 314: 1006-1010, 1986

115. Ljungman P, Larsson K, Kumlien G, Aschan J, Barkholt L, Gustafsson-Jernberg A, Lewensohn-Fuchs I and Ringdén O Leukocyte depleted, unscreened blood products give a low risk for CMV infection and disease in CMV seronegative allogeneic stem cell transplant recipients with seronegative stem cell donors. Scand J Infect Dis 34: 347-350, 2002.

116. Boeckh M, Bowden RA, Storer B, Chao NJ, Spielberger R, Tierney DK, Gallez-Hawkins G, Cunningham T, Blume KG, Levitt D and Zaia JA: Randomized, placebo-controlled, double-blind study of a cytomegalovirus-specific monoclonal antibody (MSL-109) for prevention of cytomegalovirus infection after allogeneic hematopoietic stem cell transplantation. Biol Blood Marrow Transplant 7: 343-351, 2001.

117. Raanani P, Gafter-Gvili A, Paul M, Ben-Bassat I, Leibovici L and Shpilberg O: Immunoglobulin prophylaxis in hematopoietic stem cell transplantation: Systematic review and meta-analysis J Clin Oncol 27: 770-781, 2009

118. Alexander BT, Hladnik LM, Augustin KM, Casabar E, McKinnon PS, Reichley RM, Ritchie DJ, Westervelt P and Dubberke ER: Use of cytomegalovirus intravenous immune globulin for the adjunctive treatment of cytomegalovirus in hematopoietic stem cell transplant recipients. Pharmacotherapy 30 : 554-561, 2010
119. Malagola M, Greco R, Santarone S, Natale A, Iori AP Quatrocchi L, Barbieri W, Bruzzese A, Leotta S, Carotti A, et al: CMV management with specific immunoglobulins: A multicentric retrospective analysis on 92 allotransplanted patients. Mediterr J Hematol Infect Dis 11: e2019048, 2019.

120. Grossi P, Mohacsi P, Szabolcs Z and Potena L: Cytomegalovirus immunoglobulin after thoracic transplantation: An overview. Transplantation 100 (Suppl 3): S1-S4, 2016.

121. Hammerstrom AE, Lombardi LR, Pingali SR, Rondon G, Chen J, Milton DR, Chemaly RF, Champlin RE, Gulbis A and Ciurea SO: Prevention of cytomegalovirus reactivation in haploidentical stem cell transplantation. Biol Blood Marrow Transplant 24: 353-358, 2018.

122. Boeckh M, Nichols WG, Chemaly RF, Papanicolaou GA, Wingard JR, Xie H, Syrjala KL, Flowers ME, Stevens-Ayers T, Jerome KR and Leisenring W: Valganciclovir for the prevention of complications of late cytomegalovirus infection after allogeneic hematopoietic cell transplantation: A randomized trial. Ann Intern Med 162: 1-10, 2015

123. Green ML, Leisenring W, Xie H, Mast TC, Cui Y, Sandmaier BM, Sorror ML, Goyal S, Özkök S, Yi J, et al: Cytomegalovirus viral load and mortality after haemopoietic stem cell transplantation in the era of pre-emptive therapy: A retrospective cohort study. Lancet Haematol 3: e119-e127, 2016.

124. Wloch MK, Smith LR, Boutsaboualoy S, Reyes L, Han C, Kehler J, Smith HD, Selk L, Nakamura R, Brown JM, et al: Safety and immunogenicity of a bivalent cytomegalovirus DNA vaccine in healthy adult subjects. J Infect Dis 197: 1634-1642, 2008.

125. Schleiss MR: Cytomegalovirus vaccines under clinical development. J Virus Erad 2: 198-207, 2016.

126. Kharfan-Dabaja MA, Boeckh M, Wilck MB, Langston AA, Chu AH, Wloch MK, Guterwill DF, Smith LR, Rolland AP and Kenney RT: A novel therapeutic cytomegalovirus DNA vaccine in allogeneic haemopoietic stem-cell transplantation: A randomised, double-blind, placebo-controlled, phase 2 trial. Lancet Infect Dis 12: 290-299, 2012.

127. Griffiths PD, Stanton A, McCarrell E, Smith C, Osman M, Harber M, Davenport A, Jones G, Wheeler DC, O'Beirne J, et al: Cytomegalovirus glycoprotein-B vaccine with MF59 adjuvant in transplant recipients: A phase 2 randomised placebo-controlled trial. Lancet 377: 1256-1263, 2011.

128. Vincenti F, Budde K, Merville P, Shihab F, Ram Peddi V, Shah M, Wyburn K, Cassuto-Viguier E, Weidemann A, Lee M, et al: A randomized, phase 2 study of ASP0113, a DNA-based vaccine, for the prevention of CMV in CMV-seronegative kidney transplant recipients receiving a kidney from a CMV-seropositive donor. Am J Transplant 18: 2945-2954, 2018.

129. Singh N, Winston DJ, Razonable RR, Lyon GM, Silveira FP Wagener MM, Stevens-Ayers T, Edmison B, Boeckh M and Limaye AP: Effect of preemptive therapy vs. antiviral prophylaxis on cytomegalovirus disease in seronegative liver transplant recipients with seropositive donors: A randomized clinical trial. JAMA 323: 1378-1387, 2020.

130. Einsele H, Ehninger G, Hebart H, Wittkowski KM, Schuler U, Jahn G, Mackes P, Herter M, Klingebiel T, Löffler J, et al: Polymerase chain reaction monitoring reduces the incidence of cytomegalovirus disease and the duration and side effects of antiviral therapy after bone marrow transplantation. Blood 86: 2815-2820, 1995 .

131. Tomblyn M, Chiller T, Einsele H, Gress R, Sepkowitz K, Storek J, Wingard JR, Young JA, Boeckh MJ; Center for International Blood and Marrow Researchm, et al: Guidelines for preventing infectious complications among hematopoietic cell transplantation recipients: A global perspective. Biol Blood Marrow Transplant 15: 1143-1238, 2009.

132. Natori Y, Alghamdi A, Tazari M, Miller V, Husain S, Komatsu T, Griffiths P, Ljungman P, Orchanian-Cheff A, Kumar D, et al: Use of viral load as a surrogate marker in clinical studies of cytomegalovirus in solid organ transplantation: A systematic review and meta-analysis. Clin Infect Dis 66: 617-631, 2018

133. Locatelli F, Bertaina A, Bertaina V and Merli P: Cytomegalovirus in hematopoietic stem cell transplant recipients-management of infection. Expert Rev Hematol 9: 1093-1105, 2016.

134. Limaye AP, Stapleton RD, Peng L, Gunn SR, Kimball LE, Hyzy R, Exline MC, Files DC, Morris PE, Frankel SK, et al: Effect of ganciclovir on IL-6 levels among cytomegalovirus-seropositive adults with critical Illness: A randomized clinical trial. JAMA 318: 731-740, 2017

135. Paya C, Humar A, Dominguez E, Washburn K, Blumberg E, Alexander B, Freeman R, Heaton N and Pescovitz MD; Valganciclovir Solid Organ Transplant Study Group: Efficacy and safety of valganciclovir vs. oral ganciclovir for prevention of cytomegalovirus disease in solid organ transplant recipients. Am J Transplant 4: 611-620, 2004. 
136. Winston DJ, Ho WG, Bartoni K, Du Mond C, Ebeling DF, Buhles WC and Champlin RE: Ganciclovir prophylaxis of cytomegalovirus infection and disease in allogeneic bone marrow transplant recipients. Results of a placebo-controlled, double-blind trial. Ann Intern Med 118: 179-184, 1993.

137. Griffiths P, Whitley R, Snydman DR, Singh N and Boeckh M; International Herpes Management Forum: Contemporary management of cytomegalovirus infection in transplant recipients: Guidelines from an IHMF workshop, 2007. Herpes 15: 4-12, 2008.

138. Winston DJ, Yeager AM, Chandrasekar PH, Snydman DR, Petersen FB and Territo MC; Valacyclovir Cytomegalovirus Study Group: Randomized comparison of oral valacyclovir and intravenous ganciclovir for prevention of cytomegalovirus disease after allogeneic bone marrow transplantation. Clin Infect Dis 36: 749-758, 2003.

139. Rubin RH, Lynch P, Pasternack MS, Schoenfeld D and Medearis DN Jr: Combined antibody and ganciclovir treatment of murine cytomegalovirus-infected normal and immunosuppressed BALB/c mice. Antimicrob Agents Chemother 33: 1975-1979, 1989.

140. Lukacova V, Goelzer P, Reddy M, Greig G, Reigner B and Parrott N: A physiologically based pharmacokinetic model for ganciclovir and its prodrug valganciclovir in adults and children. AAPS J 18: 1453-1463, 2016.

141. Weiner RS, Bortin MM, Gale RP, Gluckman E, Kay HE, Kolb HJ, Hartz AJ and Rimm AA: Interstitial pneumonitis after bone marrow transplantation. Assessment of risk factors. Ann Intern Med 104: 168-175, 1986.

142. Maffini E, Giaccone L, Festuccia M, Brunello L, Busca A and Bruno B: Treatment of CMV infection after allogeneic hematopoietic stem cell transplantation. Expert Rev Hematol 9: 585-596, 2016.

143. Ritchie BM, Barreto JN, Barreto EF, Crow SA, Dierkhising RA, Jannetto PJ, Tosh PK and Razonable RR: Relationship of ganciclovir therapeutic drug monitoring with clinical efficacy and patient safety. Antimicrob Agents Chemother 63: e01855-18, 2019.

144. Kim ST, Lee MH, Kim SY, Kim SJ, Kim DH, Jang JH, Kim K, Kim WS and Jung CW: A randomized trial of preemptive therapy for prevention of cytomegalovirus disease after allogeneic hematopoietic stem cell transplantation. Int J Hematol 91: 886-891, 2010.

145. El Chaer F, Shah DP and Chemaly RF: How I treat resistant cytomegalovirus infection in hematopoietic cell transplantation recipients. Blood 128: 2624-2636, 2016.

146. Einsele H, Reusser P, Bornhäuser M, Kalhs P, Ehninger G, Hebart H, Chalandon Y, Kröger N, Hertenstein B and Rohde F: Oral valganciclovir leads to higher exposure to ganciclovir than intravenous ganciclovir in patients following allogeneic stem cell transplantation. Blood 107: 3002-3008, 2006.

147. Barkam C, Kamal H, Dammann E, Diedrich H, Buchholz S, Eder M, Krauter J, Ganser A and Stadler M: Improving safety of preemptive therapy with oral valganciclovir for cytomegalovirus infection after allogeneic hematopoietic stem cell transplantation. Bone Marrow Res 2012: 874601, 2012.

148. Moretti S,Zikos P, Van Lint MT, Tedone E, Occhini D, Gualandi F, Lamparelli T, Mordini N, Berisso G, Bregante S, et al: Forscarnet vs. ganciclovir for cytomegalovirus (CMV) antigenemia after allogeneic hemopoietic stem cell transplantation (HSCT): A randomised study. Bone Marrow Transplant 22: 175-180, 1998.

149. Meesing A and Razonable RR: New developments in the management of cytomegalovirus infection after transplantation. Drugs 78: 1085-1103, 2018.

150. Marty FM, Ljungman P, Chemaly RF, Maertens J, Dadwal SS Duarte RF, Haider S, Ullmann AJ, Katayama Y, Brown J, et al: Letermovir prophylaxis for cytomegalovirus in hematopoietic-cell transplantation. N Engl J Med 377: 2433-2444, 2017.

151. Bowman LJ, Melaragno JI and Brennan DC: Letermovir for the management of cytomegalovirus infection. Expert Opin Investig Drugs 26: 235-241, 2017 .

152. Phoompoung P, Ferreira VH, Tikkanen J, Husain S, Viswabandya A, Kumar D and Humar A: Letermovir as salvage therapy for Cytomegalovirus infection in transplant recipients. Transplantation 104: 404-409, 2019.

153. Popping S, Dalm VASH, Lübke N, Cristanziano VD, Kaiser R, Boucher CAB and Van Kampen JJA: Emergence and persistence of letermovir-resistant cytomegalovirus in a patient with primary immunodeficiency. Open Forum Infectious Diseases 6: ofz375, 2019.
154. Griffiths P and Lumley S: Cytomegalovirus. Curr Opin Infect Dis 27: 554-559, 2014.

155. Beadle JR, Hartline C, Aldern KA, Rodriguez N, Harden E, Kern ER and Hostetler KY: Alkoxyalkyl esters of cidofovir and cyclic cidofovir exhibit multiple-log enhancement of antiviral activity against cytomegalovirus and herpesvirus replication in vitro. Antimicrob Agents Chemother 46: 2381-2386, 2002.

156. Bidanset DJ, Beadle JR, Wan WB, Hostetler KY and Kern ER: Oral activity of ether lipid ester prodrugs of cidofovir against experimental human cytomegalovirus infection. J Infect Dis 190: 499-503, 2004.

157. Kern ER, Collins DJ, Wan WB, Beadle JR, Hostetler KY and Quenelle DC: Oral treatment of murine cytomegalovirus infections with ether lipid esters of cidofovir. Antimicrob Agents Chemother 48: 3516-3522, 2004

158. Chemaly RF, Hill JA, Voigt S and Peggs KS: In vitro comparison of currently available and investigational antiviral agents against pathogenic human double-stranded DNA viruses: A systematic literature review. Antiviral Res 163: 50-58, 2019.

159. Gagelmann N, Ljungman P, Styczynski J and Kröger N: Comparative efficacy and safety of different antiviral agents for cytomegalovirus prophylaxis in allogeneic hematopoietic cell transplantation: A systematic review and meta-analysis. Biol Blood Marrow Transplant 24: 2101-2109, 2018.

160. Hostetler KY: Alkoxyalkyl prodrugs of acyclic nucleoside phosphonates enhance oral antiviral activity and reduce toxicity: Current state of the art. Antiviral Res 82: A84-A98, 2009.

161. Painter W, Robertson A, Trost LC, Godkin S, Lampert B and Painter G: First pharmacokinetic and safety study in humans of the novel lipid antiviral conjugate CMX001, a broad-spectrum oral drug active against double-stranded DNA viruses. Antimicrob Agents Chemother 56: 2726-2734, 2012.

162. Aldern KA, Ciesla SL, Winegarden KL and Hostetler KY: Increased antiviral activity of 1-O-hexadecyloxypropyl-[2-(14) C]cidofovir in MRC-5 human lung fibroblasts is explained by unique cellular uptake and metabolism. Mol Pharmacol 63: 678-681, 2003

163. Ciesla SL, Trahan J, Wan WB, Beadle JR, Aldern KA, Painter GR and Hostetler KY: Esterification of cidofovir with alkoxyalkanols increases oral bioavailability and diminishes drug accumulation in kidney. Antiviral Res 59: 163-171, 2003.

164. Tippin TK, Morrison ME, Brundage TM and Momméja-Marin H: Brincidofovir is not a substrate for the human organic anion transporter 1: A mechanistic explanation for the lack of nephrotoxicity observed in clinical studies. Ther Drug Monit 38: 777-786, 2016.

165. Marty FM, Winston DJ, Chemaly RF, Mullane KM, Shore TB, Papanicolaou GA, Chittick G, Brundage TM, Wilson C, Morrison ME, et al: A randomized, double-blind, placebocontrolled phase 3 trial of oral brincidofovir for cytomegalovirus prophylaxis in allogeneic hematopoietic cell transplantation. Biol Blood Marrow Transplant 25: 369-381, 2019.

166. Papanicolaou GA, Silveira FP, Langston AA, Pereira MR, Avery RK, Uknis M, Wijatyk A, Wu J, Boeckh M, Marty FM and Villano S: Maribavir for refractory or resistant cytomegalovirus infections in hematopoietic-cell or solid-organ transplant recipients: A randomized, dose-ranging, Double-blind, phase 2 study. Clin Infect Dis 68: 1255-1264, 2019.

167. Frange $P$ and Leruez-Ville M: Maribavir, brincidofovir and letermovir: Efficacy and safety of new antiviral drugs for treating cytomegalovirus infections. Med Mal Infect 48: 495-502, 2018.

168. Marty FM and Boeckh M: Maribavir and human cytomegalovirus-what happened in the clinical trials and why might the drug have failed? Curr Opin Virol 1: 555-562, 2011.

169. Piret J and Boivin G: Clinical development of letermovir and maribavir: Overview of human cytomegalovirus drug resistance. Antiviral Res 163: 91-105, 2019.

170. Bright PD, Gompels M, Donati M and Johnston S: Successful oral treatment of Ganciclovir resistant cytomegalovirus with Maribavir in the context of primary immunodeficiency: First case report and review. J Clin Virol 87: 12-16, 2017.

171. Maertens J, Cordonnier C, Jaksch P, Poiré X, Uknis M, Wu J, Wijatyk A, Saliba F, Witzke O and Villano S: Maribavir for preemptive treatment of cytomegalovirus reactivation. $\mathrm{N}$ Engl J Med 381: 1136-1147, 2019.

172. Avery RK, Marty FM, Strasfeld L, Lee I, Arrieta A, Chou S, Tatarowicz W and Villano S: Oral maribavir for treatment of refractory or resistant cytomegalovirus infections in transplant recipients. Transpl Infect Dis 12: 489-496, 2010. 
173. Germi R, Mariette C, Alain S, Lupo J, Thiebaut A, Brion JP, Epaulard O, Saint Raymond C, Malvezzi P and Morand P: Success and failure of artesunate treatment in five transplant recipients with disease caused by drug-resistant cytomegalovirus. Antiviral Res 101: 57-61, 2014.

174. Avery RK, Mossad SB, Poggio E, Lard M, Budev M, Bolwell B, Waldman WJ, Braun W, Mawhorter SD, Fatica R, et al: Utility of leflunomide in the treatment of complex cytomegalovirus syndromes. Transplantation 90: 419-426, 2010.

175. Feuchtinger T, Opherk K, Bethge WA, Topp MS, Schuster FR, Weissinger EM, Mohty M, Or R, Maschan M, Schumm M, et al: Adoptive transfer of pp65-specific T cells for the treatment of chemorefractory cytomegalovirus disease or reactivation after haploidentical and matched unrelated stem cell transplantation. Blood 116: 4360-4367, 2010

176. Walter EA, Greenberg PD, Gilbert MJ, Finch RJ, Watanabe KS Thomas ED and Riddell SR: Reconstitution of cellular immunity against cytomegalovirus in recipients of allogeneic bone marrow by transfer of T-cell clones from the donor. $\mathrm{N}$ Engl J Med 333: 1038-1044, 1995

177. Blyth E, Clancy L, Simms R, Ma CK, Burgess J, Deo S, Byth K, Dubosq MC, Shaw PJ, Micklethwaite KP and Gottlieb DJ: Donor-derived CMV-specific $\mathrm{T}$ cells reduce the requirement for CMV-directed pharmacotherapy after allogeneic stem cell transplantation. Blood 121: 3745-3758, 2013.

178. Peggs KS, Verfuerth S, Pizzey A, Khan N, Guiver M, Moss PA and Mackinnon S: Adoptive cellular therapy for early cytomegalovirus infection after allogeneic stem-cell transplantation with virus-specific T-cell lines. Lancet 362: 1375-1377, 2003.

179. Neuenhahn M, Albrecht J, Odendahl M, Schlott F, Dössinger G, Schiemann M, Lakshmipathi S, Martin K, Bunjes D, Harsdorf $\mathrm{S}$, et al: Transfer of minimally manipulated CMV-specific T cells from stem cell or third-party donors to treat CMV infection after allo-HSCT. Leukemia 31: 2161-2171, 2017.

180. Celilova S, Toret E, Adaklı Aksoy B, Ovalı E and Bozkurt C: CMV Specific T cells for treatment of CMV infection after hematopoietic stem cell transplantation in a pediatric case: First application in Turkey. Turk J Haematol 37: 65-67, 2020.

181. Tzannou I, Papadopoulou A, Naik S, Leung K, Martinez CA, Ramos CA, Carrum G, Sasa G, Lulla P, Watanabe A, et al Off-the-shelf virus-specific $\mathrm{T}$ cells to treat BK virus, human herpesvirus 6, cytomegalovirus, Epstein-Barr virus, and adenovirus infections after allogeneic hematopoietic stem-cell transplantation. J Clin Oncol 35: 3547-3557, 2017.

182. Kállay K, Kassa C, Réti M, Karászi É, Sinkó J, Goda V, Stréhn A, Csordás K. Horváth O, Szederjesi A, et al: Early experience with CliniMACS prodigy CCS (IFN-gamma) system in selection of virus-specific $\mathrm{T}$ cells from third-party donors for pediatric patients with severe viral infections after hematopoietic stem cell transplantation. J Immunother 41: 158-163, 2018.

183. Ogonek J, Verma K, Schultze-Florey C, Varanasi P, Luther S Schweier P, Kühnau W, Göhring G, Dammann E, Stadler M, et al: Characterization of high-avidity cytomegalovirus-specific T cells with differential tetramer binding coappearing after allogeneic stem cell transplantation. J Immunol 199: 792-805, 2017.

184. Bao L, Cowan MJ, Dunham K, Horn B, McGuirk J, Gilman A and Lucas KG: Adoptive immunotherapy with CMV-specific cytotoxic T lymphocytes for stem cell transplant patients with refractory CMV infections. J Immunother 35: 293-298, 2012.

185. Koehne G, Hasan A, Doubrovina E, Prockop S, Tyler E, Wasilewski G and O'Reilly RJ: Immunotherapy with donor T cells sensitized with overlapping pentadecapeptides for treatment of persistent cytomegalovirus infection or viremia. Biol Blood Marrow Transplant 21: 1663-1678, 2015.

186. Pei XY, Zhao XY, Chang YJ, Liu J, Xu LP, Wang Y, Zhang XH, Han W, Chen YH and Huang XJ: Cytomegalovirus-specific T-cell transfer for refractory cytomegalovirus infection after haploidentical stem cell transplantation: The quantitative and qualitative immune recovery for cytomegalovirus. J Infect Dis 216: 945-956, 2017.

187. Peggs KS, Thomson K, Samuel E, Dyer G, Armoogum J, Chakraverty R, Pang K, Mackinnon S and Lowdell MW: Directly selected cytomegalovirus-reactive donor T cells confer rapid and safe systemic reconstitution of virus-specific immunity following stem cell transplantation. Clin Infect Dis 52 49-57, 2011

188. Micklethwaite K, Hansen A, Foster A, Snape E, Antonenas V, Sartor M, Shaw P, Bradstock K and Gottlieb D: Ex vivo expansion and prophylactic infusion of CMV-pp65 peptide-specific cytotoxic T-lymphocytes following allogeneic hematopoietic stem cell transplantation. Biol Blood Marrow Transplant 13: 707-714, 2007.
189. Houghtelin A and Bollard CM: Virus-specific T cells for the immunocompromised patient. Front Immunol 8: 1272, 2017.

190. Einsele H, Roosnek E, Rufer N, Sinzger C, Riegler S, Löffler J, Grigoleit U, Moris A, Rammensee HG, Kanz L, et al: Infusion of cytomegalovirus (CMV)-specific T cells for the treatment of CMV infection not responding to antiviral chemotherapy. Blood 99: 3916-3922, 2002.

191. Perruccio K, Tosti A, Burchielli E, Topini F, Ruggeri L, Carotti A, Capanni M, Urbani E, Mancusi A, Aversa F, et al: Transferring functional immune responses to pathogens after haploidentical hematopoietic transplantation. Blood 106: 4397-4406, 2005.

192. Gary R, Aigner M, Moi S, Schaffer S, Gottmann A, Maas S, Zimmermann R, Zingsem J, Strobel J, Mackensen A, et al: Clinical-grade generation of peptide-stimulated CMV/EBV-specific T cells from G-CSF mobilized stem cell grafts. J Transl Med 16: 124, 2018.

193. Friedenstein AJ, Deriglasova UF, Kulagina NN, Panasuk AF, Rudakowa SF, Luriá EA and Ruadkow IA: Precursors for fibroblasts in different populations of hematopoietic cells as detected by the in vitro colony assay method. Exp Hematol 2: 83-92, 1974.

194. Méndez-Ferrer S, Michurina TV, Ferraro F, Mazloom AR, Macarthur BD, Lira SA, Scadden DT, Ma'ayan A, Enikolopov GN and Frenette PS: Mesenchymal and haematopoietic stem cells form a unique bone marrow niche. Nature 466: 829-834, 2010.

195. Martínez-Peinado P, Pascual-García S, Roche E and Sempere-Ortells JM: Differences of clonogenic mesenchymal stem cells on immunomodulation of lymphocyte subsets. J Immunol Res 2018: 7232717, 2018.

196. Wolff D, Schleuning M, von Harsdorf S, Bacher U, Gerbitz A, Stadler M, Ayuk F, Kiani A, Schwerdtfeger R, Vogelsang GB, et al: Consensus conference on clinical practice in chronic GVHD: Second-line treatment of chronic Graft-versus-Host disease. Biol Blood Marrow Transplant 17: $1-17,2011$.

197. Tse WT, Pendleton JD, Beyer WM, Egalka MC and Guinan EC: Suppression of allogeneic T-cell proliferation by human marrow stromal cells: Implications in transplantation. Transplantation 75: 389-397, 2003

198. Malcherek G, Jin N, Huckelhoven AG, Mani J, Wang L, Gern U, Diehlmann A, Wuchter P, Schmitt A, Chen B, et al: Mesenchymal stromal cells inhibit proliferation of virus-specific $\mathrm{CD}^{+} \mathrm{T}$ cells. Leukemia 28: 2388-2394, 2014

199. Elmaagacli AH, Steckel NK, Koldehoff M, Hegerfeldt Y, Trenschel R, Ditschkowski M, Christoph S, Gromke T, Kordelas L, Ottinger HD, et al: Early human cytomegalovirus replication after transplantation is associated with a decreased relapse risk: Evidence for a putative virus-versus-leukemia effect in acute myeloid leukemia patients. Blood 118: 1402-1412, 2011.

200. Inagaki J, Noguchi M, Kurauchi K, Tanioka S, Fukano R and Okamura J: Effect of cytomegalovirus reactivation on relapse after allogeneic hematopoietic stem cell transplantation in pediatric acute leukemia. Biol Blood Marrow Transplant 22: 300-306, 2016

201. Litjens NHR, van der Wagen L, Kuball J and Kwekkeboom J: Potential beneficial effects of cytomegalovirus infection after transplantation. Front Immunol 9: 389, 2018.

202. Yoon JH, Lee S, Kim HJ, Jeon YW, Lee SE, Cho BS, Lee DG, Eom KS, Kim YJ, Min CK, et al: Impact of cytomegalovirus reactivation on relapse and survival in patients with acute leukemia who received allogeneic hematopoietic stem cell transplantation in first remission. Oncotarget 7: 17230-17241, 2016.

203. Jang JE, Kim SJ, Cheong JW, Hyun SY, Kim YD, Kim YR, Kim JS and Min YH: Early CMV replication and subsequent chronic GVHD have a significant anti-leukemic effect after allogeneic HSCT in acute myeloid leukemia. Ann Hematol 94: 275-282, 2015

This work is licensed under a Creative Commons Attribution-NonCommercial-NoDerivatives 4.0 International (CC BY-NC-ND 4.0) License. 